\title{
Comparative bioaccumulation of polycyclic aromatic hydrocarbons from sediment by two infaunal invertebrates
}

\author{
J. P. Meador, E. Casillas, C. A. Sloan, U. Varanasi \\ Environmental Conservation Division, Northwest Fisheries Science Center, National Marine Fisheries Service, \\ National Oceanic and Atmospheric Administration, 2725 Montlake Blvd East, Seattle, Washington 98112, USA
}

\begin{abstract}
Bioaccumulation of polycyclic aromatic hydrocarbons (PAHs) from field-contaminated sediments by 2 infaunal invertebrates, Rhepoxynius abronius (a non-deposit feeding amphipod) and Armandia brevis (a non-selective, deposit-feeding polychaete), was examined. Sediments were selected over a large geographical area of the Hudson-Raritan estuary (New York, USA) to assess the potential for bioaccumulation from a typical urban estuary. Assessment of bioaccumulation in these invertebrates is important because of the need to understand their health and role in ecosystem functioning and because they are vectors of sediment-associated contaminants to demersal fish. Our study compared the response of these 2 species over a wide range of PAH concentrations to learn how feeding mode may affect contaminant accumulation. After $10 \mathrm{~d}$ of exposure to sediments, we assessed the tissue concentrations of 24 PAHs and found no significant differences for the low molecular weight PAHs (LPAHs) between $R$. abronius and A. brevis. There was, however, a large differential observed between species for bioaccumulated high molecular weight PAHs (HPA.Hs). Because we assumed that the amphipod was not feeding and most of its tissue burden was received through ventilation of interstitial water (IW), we concluded that IW was probably the major route of uptake for the LPAHs for both species and that sediment ingestion was a much more important uptake route of HPAHs for the polychaete. Analysis of correlations between amphipod and polychaete tissue burdens found that the species were responding similarly to a gradient of PAH concentrations in sediment; however, when the associations between concentrations in tissue and exposure matrix (e.g. sediment, IW) were examined the interpretations were less clear. Concentrations of PAHs in IW and sediment indicated that the partition coefficient $\left(K_{\mathrm{oc}}\right)$ was generally 2 orders of magnitude higher than expected for LPAHs and highly variable between sites for HPAHs. When $K_{o c}$ was re-calculated using free PAH, it became much less variable and was uniformly elevated above the predicted values. The BAF $\mathrm{F}_{\text {loc }}$ (lipid/organic carbon normalized bioaccumulation factor) in the polychaete was generally consistent over the series of PAHs, as expected, and when metabolism and pre-steady state conditions were considered, partitioning of PAHs between tissue and sediment was relatively close to the theoretical maximum. Despite much lower than predicted IW concentrations, the LPAH bioconcentration factors (BCF) for the amphipod were close to expected, but the HPAH BCFs were close to the predicted values only when expressed in terms of the free PAH. From these data, and previous studies, we conclude that there was a significant reduction in bioavailability of HPAHs to $R$. abronius due to partitioning of HPAHs to dissolved organic carbon.
\end{abstract}

KEY WORDS: Bioaccumulation - Bioconcentration - PAHs - Sediment-water partitioning - Interstitial water $\cdot$ Infauna

\section{INTRODUCTION}

Contaminated sediments in urban areas are a concern for living marine resources and human health. The ability to assess bioaccumulation in these urban areas is important for understanding food-web dynamics and transfer of contaminants throughout the eco- system. Furthermore, concerns of contaminant transfer to humans can be assessed by understanding the processes which control bioaccumulation and foodweb transfer to economically important species.

In aquatic toxicology it is important to determine what proportion of the total toxicant is available to an organism in order to adequately characterize the 
degree to which bioaccumulation and adverse effects can occur. Some benthic surveys indicate that organics and metals occur at high levels $\left(\mu \mathrm{g} \mathrm{g}^{-1}\right)$ in sediment and may be factors in the elimination of certain populations of fish or invertebrates (Gray 1979, Swartz et al. 1986, Swartz et al. 1994). In other situations, contaminants may be high, but determination of adverse effects may not be obvious. With knowledge about environmental concentrations, the factors controlling bioavailability, the route of exposure, and the doseresponse relationship, we should be able to predict tissue concentrations and the potential for a toxic response.

The route of uptake of a chemical to the organism will have a major influence on the bioaccumulation of many chemical contaminants. It has been shown that when sediment is present, accumulation and toxicity of a chemical can be reduced many-fold for some organisms (Knezovich \& Harrison 1988, Schrap \& Opperhuizen 1990) due to the ability of sediment to sorb or complex the chemical and reduce its free concentration. Other studies have shown an increase in tissue concentration when exposed to sediment over that from water-only exposures, which is probably due to sediment ingestion (Lynch \& Johnson 1982, McLeese \& Burridge 1987). Recently, it has been postulated that interstitial water (IW) exposure is the main route of uptake of sediment-associated contaminants for marine animals that live under the sediment's surface (infauna) or are closely associated with it (Adams 1987). The consequences are that even though waterborme concentrations of hydrophobic chemicals in the presence of sediment will be much reduced, bioaccumulation based on total water concentration is basically the same whether in a water-only system or an interstitial water/sediment system. Interestingly, it has also been proposed that the route of exposure may not be important for infaunal organisms because, given enough time, their tissues should come into steady state with both the water and sediment phases (Bierman 1990) (assuming that water and sediment are in equilibrium). Conversely, for a non-sediment ingester, steady-state tissue concentrations may be very different reflecting exposure to overlying-water and diet. Of course, the prey's exposure and ability to regulate or metabolize contaminants will greatly influence tissue burdens in the target species.

Recently, Equilibrium Partitioning Theory (EPT) was developed to assess the potential for deleterious effects on animals exposed to contaminants associated with sediment. The basis of EPT is that chemicals in sediment and IW come into equilibrium, and thus IW concentrations can be predicted if we know organic carbon and bulk sediment concentrations. With the ability to predict IW concentrations, toxicity assessment can be conducted by employing the large acute-response, water-quality database that has been generated over the years for various species in water-only tests. Recent literature indicates that EPT accurately predicts the IW concentration for most organic compounds and some metals (Di Toro et al. 1991). EPT is valid, of course, only if sediment-water partitioning behavior is as expected. This method of assessing sediment toxicity is currently being pursued by the U.S. EPA (Di Toro et al. 1991) and by agencies in other countries (Van Der Kooij et al. 1991) and may be used to generate Sediment Quality Criteria, which are contaminant-specific numerical values for protection of aquatic life.

In our experiments we compared the abilities of 2 infaunal species, an amphipod (Rhepoxynius abronius) and a polychaete (Armandia brevis), to bioaccumulate polycyclic aromatic hydrocarbons (PAHs) from 10 field-contaminated sediments. Our intent with this study was to compare the body burden of these 2 species with bulk sediment and IW concentrations and to explore patterns of accumulation over a hydrophobic series of PAHs. Many studies have been performed with PAHs spiked onto sediment, but very few have examined field-contaminated sediments. A few authors have expressed concern about the comparability of bioaccumulation results from studies using spiked sediments with those using field sediments (Varanasi et al. 1985, McElroy et al. 1989) because of possible differences in contaminant partitioning behavior and hence altered bioavailability.

Rhepoxynius abronius is an omnivore that feeds on meiofauna, diatoms, and detritus (Oliver et al. 1982, Oakden 1984) and generally does not ingest sediment for nutrition. Because the standard sediment bioassay for estuarine amphipods (ASTM 1990) does not include feeding, and bioassay sediments may be screened for native infauna or may be dewatered for 1 to $2 \mathrm{wk}$, prey species for these amphipods are generally not expected. The polychaete is a member of the family Opheliidae, whose members are considered to be nonselective deposit feeders (reviewed by Fauchald \& Jumars 1979). In the present study we expected, a priori, that amphipod tissue burdens of PAHs would reflect input from IW because of their feeding habits and lack of suitable dietary input, and that the polychaete tissue burdens would reflect the bulk sediment concentrations of PAHs because of its indiscriminate ingestion of sediment.

\section{METHODS}

Sediment was collected using a $0.1 \mathrm{~m}^{2}$ Smith-MacIntyre grab at 8 sites in the Hudson-Raritan estuary. New York, USA, during May 1991. We chose samples over a large area $\left(-4000 \mathrm{~km}^{2}\right)$ of the Hudson-Raritan estuary 
which may represent conditions in similar large urban estuaries. These sites were selected from a larger group of sites based on screening-level concentrations (Krahn et al. 1991) of sediment PAHs in order to provide a range in concentration. We know of no unusual sources of PAHs to these sediments, such as coal particles. At each site, the top $2 \mathrm{~cm}$ of sediment was removed from grab samples and placed in $1 \mathrm{l}$ glass jars rinsed with methylene chloride and secured with Teflon-lined lids. Each jar was purged with nitrogen, inverted, and placed on ice for shipment to Seattle, Washington, USA. Upon arrival, sediments were held at $4 \pm 1^{\circ} \mathrm{C}$ for 6 to $8 \mathrm{wk}$ prior to the tests. A review of the environmental characteristics of Raritan Bay can be found in Jeffries (1962) and the site locations in Rice et al. (1995). Two additional sites, 1 highly contaminated (Elliott Bay) and 1 very clean (West Beach), from Puget Sound, Washington, were included as positive and negative controls, respectively. We considered all sites as 'treatment' sites except West Beach and Rockaway, which were used as negative controls because they contained very low concentrations of PAHs. Only treatment sites were used to calculate accumulation factors and generate correlations.

Individuals of the amphipod Rhepoxynius abronius (Phoxacephalidae) were collected during June 1991 on West Beach, Whidbey Island, Washington, by dredging in about $7 \mathrm{~m}$ of water $[-4 \mathrm{~m}$ mean lower low water (MLLW)]. The polychaete Armandia brevis was collected during June 1991, on the intertidal mudflats of Mitchell Bay on San Juan Island, Washington. Both species were kept in the lab for $10 \mathrm{~d}$ before the bioassay was started. The salinity, temperature, and $\mathrm{pH}$ for each beaker in each experiment reflected ambient conditions are were in the range of 30 to $32 \%, 10$ to $11^{\circ} \mathrm{C}$, and 7.8 to 8.1 , respectively. Neither species was fed in the laboratory or during the experiments. Because the sediments were dewatered and stored under nitrogen for 6 to $8 \mathrm{wk}$, we assumed that there would be no invertebrate prey for the amphipod. A previous study (Meador 1993) found declining total lipid content in $R$. abronius due to laboratory holding, which indicated that individuals were receiving less than adequate dietary input.

Separate $10 \mathrm{~d}$ experiments were conducted to assess bioaccumulation for each species and for determination of PAH concentrations in interstitial water. To avoid particle sorting, sediments were not homogenized, stirred, or screened. On Day 0, $200 \mathrm{ml}(-300 \mathrm{~g}$ dry weight) of sediment was added to $1 \mathrm{l}$ glass Pyrex beakers along with $800 \mathrm{ml}$ of $5 \mu \mathrm{m}$ filtered seawater and allowed to sit undisturbed overnight. On Day 1 , the overlying water was carefully drained and fresh overlying water was added. In the bioaccumulation tests, 20 adults were added to each beaker on Day 3. The polychaete test contained duplicate beakers and the amphipod test was run with 5 replicates. Overlying water in the beakers was not changed (static), and the beakers were gently aerated and covered with a watch glass. A 16 h light: 8 h dark cycle was maintained. On Day 13, invertebrates were sieved from sediment, placed in clean water and allowed to evacuate their guts for $6 \mathrm{~h}$. Purge water was changed hourly, and there was no sediment visible in the guts at the end of the purge period. For the polychaetes, a mucous-sediment mass was found in the purge water and discarded. In the amphipod bioaccumulation bioassay, mortality was under $10 \%$, except for The Battery site which produced $15 \%$ mortality. Mortality for the polychaete test never exceeded $12.5 \%$. Test beakers were examined twice daily and individuals were never observed on the sediment surface. Approximately 75 amphipods and 30 polychaetes for each sediment site were frozen at $-80^{\circ} \mathrm{C}$ until analyzed for organic chemicals. Sample sizes for organic chemical determination were -0.2 to $0.5 \mathrm{~g}$ wet weight. The bioaccumulation tests were conducted for $10 \mathrm{~d}$ because our intent was to compare species and it was felt that a longer-term exposure would be complicated by declining lipid levels in amphipods (Meador 1993). Due to insufficient sediment, bioaccumulation of PAHs in the polychaete was not determined for Elliott Bay and Ward Point.

For determination of PAHs in IW, 250 to $400 \mathrm{ml}$ of sediment was added to duplicate beakers. On Day 1 , the overlying water was exchanged in each beaker, which were then aerated and allowed to stand in a water bath for $13 \mathrm{~d}$ total. Throughout the $13 \mathrm{~d}$, no beaker showed any signs of having anoxic sediment. Twenty polychaete worms were added to each beaker on Day 3 to mimic conditions in the bioaccumulation tests. Interstitial water was recovered from sediment by centrifugation. A polycarbonate (PC) bottle $(250 \mathrm{ml})$ was fashioned into a separation device by cutting off the bottom and placing dual polystyrene petri-dish bottoms (Falcon number 1006) with drill holes, back to back, inside the PC bottle near the screwcap end. A layer of Nitex netting was placed on top of the petri bottoms. Sediment was placed inside the container and centrifuged at $4^{\circ} \mathrm{C}$, with the screwcap end down, at $900 \times g$ for $20 \mathrm{~min}$. Four devices were used concurrently. Interstitial water was collected and centrifuged again in clean, unmodified polycarbonate bottles at $2400 \times g$ for $20 \mathrm{~min}$, which was sufficient to remove particles larger than $0.1 \mu \mathrm{m}$, and then extracted for PAHs. Approximately 90 to $150 \mathrm{ml}$ of IW was separated from the sediment for each site and all but $10 \mathrm{ml}$ was used for PAH analysis. All contaminated sites were sampled for IW except for Union City which had insufficient sediment volume.

We allowed invertebrates to evacuate their guts for $6 \mathrm{~h}$ because we felt that this was sufficient time for 
emptying and because of the risk of low molecular weight PAHs (LPAHs) being rapidly eliminated (Lyes 1979, Widdows et al. 1983). To assess the possibility of sediment in the guts, we conducted a separate experiment of gut purging in Armandia brevis with ${ }^{14} \mathrm{C}$ radiolabeled polychlorinated biphenyl (PCB) (Arolcor 1254). Amphipods were not studied because sediment ingestion was assumed not to occur (authors' pers. obs.). Polychaetes were allowed to feed on ${ }^{14} \mathrm{C}$ PCB spiked sediment for $10 \mathrm{~d}$ and then placed in clean seawater for purging. Tissues were then assayed at 0 , 6 , and $24 \mathrm{~h}$. There was a general decline in body burden from 0 to $6 \mathrm{~h}$, and less so for 6 to $24 \mathrm{~h}$; however, the variance for each group was relatively large (coefficient of variation 33 to $100 \%$ ). The mean tissue burdens of ${ }^{14} \mathrm{CPCB}$ between 6 and $24 \mathrm{~h}$ were not significantly different. To further address gut purging, we redigested the original tissue digests of both species with hydrofluoric acid in order to release possible sedimentary iron for determination of sediment in the gut. We determined the iron content of polychaetes and amphipods starved $5 \mathrm{~d}$ to be 630 and $168 \mu \mathrm{g} \mathrm{g}^{-1}$ dry wt, respectively. Analysis of the redigested tissue indicated that there may have been small amounts of sediment contributing to the body burden. The range in percentage of the total tissue dry weight that could have been due to sediment was 0 to $13.9 \%$ over all sites [mean (SD) $6.0 \%(4.1)$ ] for the polychaete and 0 to $2.6 \%$ over all sites $[0.4 \%(0.9)]$ for the amphipod. For the polychaete, individuals exposed to sediment from the Union City site had the highest value $(13.9 \%)$ and sample means from the rest of the sites were mostly below $6 \%$. Because the polychaete is a non-selective deposit feeder (Fauchald \& Jumars 1979, authors' pers. obs.), we feel that any potential contribution of PAHs in small amounts of sediment to the overall tissue burden would be negligible.

Amphipod dry: wet weight ratios were determined according to Meador et al. (1993). The mean (SD) dry: wet ratio for Rhepoxynius abronius was $0.26(0.02)$ and for Armandia brevis was $0.22(0.02)$. Total lipid was determined by homogenizing approximately 75 amphipods or 15 polychaetes ( -33 to $66 \mathrm{mg}$ dry wt) in a Tekmar Tissuemiser and extracting lipids according to a modified Bligh and Dwyer technique (Herbes \& Allen 1983) which was designed for small sample sizes. Residues were weighed to $0.01 \mathrm{mg}$ on a Mettler AT261 balance. Mean (SD) lipid content for $A$. brevis was $5.6 \%(0.5)$ and for $R$. abronius was $6.9 \%(1.2)$ of dry weight.

Dissolved organic carbon (DOC) was sampled with a glass syringe, and solutions were filtered with a preashed $0.45 \mu \mathrm{m}$ filter, stored frozen in a glass vial (cleaned of organics) with a Teflon lid and analyzed by the ultraviolet promoted persulfate oxidation tech- nique (Standard Methods No. 505a) (APHA 1985) using a Shimadzu Total Organic Carbon Analyzer (Model 5000). Total organic carbon (TOC) in sediments was measured according to the method of Hedges \& Stern (1984) using a Carlo Erba CHN analyzer Model 1106. The certified standard was acetanilide from Sanda, Inc. Sediment grain size composition was determined by the pipette method as described by Buchanan \& Kain (1971).

Chemical analyses. LPAHs are low molecular weight PAHs consisting of 2 and 3 ring compounds, and HPAHs are high molecular weight PAHs which in this study consisted of 4,5, and 6 ring compounds. Sediment and tissue samples were analyzed for PAHs using the procedures of Sloan et al. (1993). Briefly, sediment and tissue were solvent extracted by homogenization with dichloromethane plus sodium sulfate for absorbing the water and surrogate standards for measuring the recovery of the analytes. The solvent extract was separated from the solid matrix by centrifugation, then filtered through gravity-flow columns of silica/ alumina to remove highly polar compounds. The filtered extracts were concentrated to $1 \mathrm{ml}$ for sediments or $300 \mu \mathrm{l}$ for tissues. A $250 \mu \mathrm{l}$ aliquot of each extract was fractionated by a Model 8800 HPLC (high-performance liquid chromatograph) (Spectra-Physics, Mountain View, CA, USA) using two $22.5 \times 250 \mathrm{~mm}, 100 \AA$ Phenogel ${ }^{\mathrm{TM}}$ size-exclusion columns (Phenomenex, Inc., Torrance, CA) with $7 \mathrm{ml} \mathrm{min} \mathrm{m}^{-1}$ of dichloromethane as the mobile phase, to isolate the PAHs from the higher molecular weight compounds such as biogenic matter. The resulting fraction containing the PAHs was exchanged into hexane and concentrated to a final volume of $250 \mu$ l for sediment or $120 \mu$ for tissue, including a gas chromatography (GC) internal standard. The PAHs were determined by $\mathrm{GC}$ with mass spectrometric detection (GC/MS) using a $30 \mathrm{~m} \times 0.25 \mathrm{~mm} \mathrm{DB}-5$ capillary column ( $J$ \& W Scientific, Rancho Cordova, CA) in a Model 5890 Il GC interfaced to a Model $5970 \mathrm{~B}$ MSD with a UNIX Chemstation data system and a Model 7673 injector (Hewlett-Packard, Avondale, PA, USA). A $3 \mu$ l aliquot of the concentrated HPLC fraction was injected splitless, with the split valve opened after $0.5 \mathrm{~min}$. After a $1 \mathrm{~min}$ hold at $50^{\circ} \mathrm{C}$, the oven temperature was increased at $4^{\circ} \mathrm{C} \mathrm{min}^{-1}$ to $300^{\circ} \mathrm{C}$ then was held for 10 min. Data was acquired using full-scan mode for sediment samples and using sequenced selected-ion monitoring for tissue samples. For quality assurance, sets of approximately 12 samples included a method blank and a sample of NIST (National Institute of Standards and Technology) Marine Sediment Standard Reference Material (SRM) 1941 or NIST Mussel SRM 1974. For both HPLC and GC/MS quality control, calibration solutions were analyzed at the beginning, middle and end of each set of samples. The quantita- 
tion range of the GC/MS was demonstrated by analyzing multi-level calibration solutions with each set of samples

Water samples were solvent extracted by agitation with dichloromethane along with surrogate standards for measuring the recovery of the analytes. The solvent extract was separated from the water using a separatory funnel, then dried by mixing it with sodium sulfate. The extract was exchanged into hexane during concentration to a final volume of $150 \mu \mathrm{l}$, including a $\mathrm{GC}$ internal standard. The PAHs were determined by GC/MS as described above using sequenced selectedion monitoring. For quality assurance, a method blank and a sample of spiked deionized water were also analyzed. For GC/MS quality control, a calibration solution was analyzed at the beginning, middle and end of the set of samples. The quantitation range of the GC/MS was demonstrated by analyzing multi-level calibration solutions.

The precision and accuracy of replicate analyses were high. The mean (SD) coefficient of variation (CV) for replicate analyses over all $24 \mathrm{PAH}$ analytes (i.e. $24 \mathrm{CVs}$ calculated for PAHs per replicate) was $39 \%(25)(\mathrm{n}=2$ ) for IW using 2 treatment replicates, $15.9 \%(11.3)(n=3)$ for NIST sediment SRM 1941, and $13.3 \%(13.8)(n=5)$ for NIST mussel SRM 1974. The mean (SD) percentage recoveries of the surrogate standards naphthalene-d8, acenaphthalene-d10, and benzo[a]pyrene-d12 were as follows: $73.9 \%$ (4.9), $82.5 \%(4.1)$, and $97.5 \%$ (8.9) for IW; $82.1 \%(5.1)$, $88.5 \%(4.3)$, and $94.2 \%$ (4.9) for sediment; and $80.3 \%$ (7.2), 87.5\% (6.3), and 103.3\% (11.8) for tissue. The surrogate standards were also used as internal standards to correct for losses during analytical determinations. The concentrations of analytes from naphthalene through 2-methylnaphthalene were corrected with the percent recovery of naphthalene-d8, analytes from biphenyl through fluoranthene were corrected with acenaphthene-d10, and analytes from chrysene through indeno[1,2,3-cd] pyrene were corrected with benzo[a]pyrene-d12. The limit of detection (LOD) for our smallest sediment (dry wt), tissue (dry wt), and IW samples was in the range of 1 to $4 \mathrm{ng} \mathrm{g}^{-1}, 5$ to $50 \mathrm{ng}$ $\mathrm{g}^{-1}$, and 0.0005 to $0.001 \mathrm{ng} \mathrm{ml}^{-1}$ for LPAHs and 0.3 to $0.5 \mathrm{ng} \mathrm{g}^{-1}, 0.5$ to $3.5 \mathrm{ng} \mathrm{g}^{-1}$, and 0.0002 to $0.0004 \mathrm{ng}$ $\mathrm{ml}^{-1}$ for HPAHs, respectively.

Statistical analyses. To compare the body burden between species for each PAH, a paired t-test for dependent samples was performed. The significance level was corrected for the number of comparisons made by setting the $\alpha$ level to 0.05 divided by the number of comparisons (Milliken \& Johnson 1984). Product-moment correlations ( $r$ ) (Pearson correlations) were computed for log-transformed concentrations because these data were generally log-normally dis- tributed. Standard deviations (SD) are reported to show the range in the data and the standard error of the mean (SEM) is reported when comparisons of means are intended.

The following formulae were used to determine the organic-carbon normalized sediment concentration $\left(\right.$ Sed $\left._{o c}\right)$, the octanol-water partition coefficient $\left(K_{\text {ow }}\right)$, the sediment-water partition coefficient $\left(K_{o c}\right)$ based on total and free PAH in IW, the DOC-IW partition coefficient $\left(K_{\mathrm{doc}}\right)$, the concentration of freely dissolved PAH in interstitial ( $\mathrm{IW}_{\text {tree }}$ ), the bioconcentration factor $(\mathrm{BCF})$, and the lipid and sediment organic carbon (oc) normalized bioaccumulation factor $\left(\mathrm{BAF}_{\mathrm{loc}}\right)$.

$$
\begin{aligned}
& \operatorname{Sed}_{o c}=\left([\text { sediment }] / f_{o c}\right) \\
& K_{\text {ow }}=[\text { octanol }] /[\text { water }] \\
& K_{\text {oc, total }}=\left([\text { sediment }] / f_{\text {oc }}\right) /\left[I W_{\text {total }}\right] \\
& K_{\text {oc, free }}=\left([\text { sediment }] / f_{\text {oc }}\right) /\left[\mathrm{IW}_{\text {free }}\right] \\
& K_{\text {dac }}=\left[\mathrm{IW}_{\text {bound }}\right] /\left(\left[\mathrm{IW}_{\text {free }}\right] \cdot f_{\text {doc }}\right) \\
& \mathrm{IW}_{\text {free }}=\left[\mathrm{IW}_{\text {total }}\right] /\left(1+f_{\text {doc }} \cdot K_{\text {doc }}\right) \\
& \mathrm{BCF}_{\text {total }}=[\text { tissue }] /\left[\mathrm{IW}_{\text {total }}\right] \\
& \mathrm{BCF}_{\text {free }}=[\text { tissue }] /\left[\mathrm{IW}_{\text {free }}\right] \\
& \left.\mathrm{BAF}_{\text {loc }}=\left([\text { tissue }] / f_{\text {l1p }}\right) /\left[\operatorname{Sed}_{\mathrm{oc}}\right]\right)
\end{aligned}
$$

where $f_{\mathrm{oc}}$ and $f_{\mathrm{doc}}$ are the fractions of organic carbon in sediment ( $\mathrm{g} \mathrm{g}^{-1}$ dry $\mathrm{wt}$ ) and IW $\left(\mathrm{g} \mathrm{ml}^{-1}\right)$, respectively; IW is interstitial water, IW $\mathrm{Wtat}_{\text {t }}$ IW $_{\text {free }}$ and IW $\mathrm{W}_{\text {bound }}$ are the concentrations of total, freely dissolved, and bound PAH in IW; and $f_{\text {Lip }}$ is the fraction of tissue dry weight that is lipid $\left(\mathrm{g} \mathrm{g}^{-1}\right.$ dry wt). We used a $K_{\text {doc }}$ of $0.1 K_{\text {ow }}$ which was chosen from studies where this parameter was empirically determined (Landrum et al. 1985, Chiou et al. 1987. McCarthy et al. 1989). We used the acronym $\mathrm{BAF}_{\mathrm{loc}}$ [also known as the accumulation factor $(\mathrm{AF})]$ because of the historical usage of BAF to denote bioaccumulation. All sediment and tissue concentrations expressed as ng $\mathrm{g}^{-1}$ dry weight, except where noted. We are unsure how close our exposures were to steady-state conditions; however, recent work indicates that $10 \mathrm{~d}$ is sufficient to be at steady state for the LPAHs and within a factor of 2 to 3 for most HPAHs (Lee et al. 1993, Landrum et al. 1994; for a review see Meador et al. 1995).

The predicted steady-state BCFs for PAHs were taken from Landrum (1988) and Landrum et al. (1994) for amphipod species (Diporeia spp.) which are known to exhibit very weak or nonexistent biotransformation activity towards PAHs. Therefore, these predicted BCFs, which are expected to be positively correlated to $K_{\text {ow }}$ (Mackay 1982), are assumed to represent maximum steady-state values. Our predicted BCF for benzolalpyrene is the mean of the steady-state BCFs given in Landrum et al. (1994) for benzo[a]pyrene and tetrachlorobiphenyl which have $\log K_{\text {ow }}$ values of 5.98 and 5.85, respectively. The predicted BCF for biphenyl was determined with the ratio of the uptake and elimi- 
Table 1 Sites of collection and miscellaneous measurements. Fines: particles less than $63 \mu \mathrm{m}$ (silt plus clay). TOC: total organic carbon as a percentage of sediment dry weight. DOC: dissolved organic carbon in interstitial water (IW). Bold values for DOC were considered 'low' for determination of the DOC-IW partition coefficient $\left(K_{d o c}\right)$. Ambient SW: seawater flowing into the lab. Sum PAHs: concentration (in nmol g ${ }^{-1}$ dry wt) of all 24 polycyclic aromatic hydrocarbon (PAH) analytes in tissue. Ratio P/A: polychaete/amphipod for summed PAHs. Amphipod: Rhepoxynius abronius; polychaete: Armandia brevis. -: data not available

\begin{tabular}{|c|c|c|c|c|c|c|c|c|}
\hline \multirow[t]{2}{*}{ Site } & \multirow{2}{*}{$\begin{array}{l}\text { Latitude } \\
\text { (N) }\end{array}$} & \multirow{2}{*}{$\begin{array}{l}\text { Longitude } \\
\text { (W) }\end{array}$} & \multirow{2}{*}{$\begin{array}{c}\text { Fines } \\
(\%)\end{array}$} & \multirow{2}{*}{$\begin{array}{c}\text { TOC } \\
(\%)\end{array}$} & \multirow{2}{*}{$\begin{array}{c}\mathrm{DOC} \\
\left(\mathrm{mg} \mathrm{l}^{-1}\right)\end{array}$} & \multicolumn{2}{|c|}{ Sum PAHs } & \multirow{2}{*}{$\begin{array}{l}\text { Ratic } \\
\text { P/A }\end{array}$} \\
\hline & & & & & & Amphipod & Polychaete & \\
\hline Battery & $40^{\circ} 42.3^{\prime}$ & $74^{\circ} 01.5^{\prime}$ & 53 & 2.2 & 257 & 7.1 & 22.1 & 3.1 \\
\hline Chapel Hill & $40^{\circ} 33.9^{\prime}$ & $74^{\circ} 03.0^{\prime}$ & 3 & 0.53 & 7 & 3.0 & 11.1 & 3.7 \\
\hline Elliott Bay & $47^{\circ} 35.5^{\prime}$ & $122^{\circ} 21.0^{\prime}$ & - & 2.2 & 231 & 80.3 & - & - \\
\hline Narrows & $40^{\circ} 38.6^{\prime}$ & $74^{\circ} 03.3^{\prime}$ & 5 & 0.30 & 16 & 4.7 & 14.5 & 3.1 \\
\hline Newark & $40^{\circ} 42.4^{\prime}$ & $74^{\circ} 07.1^{\prime}$ & 38 & 1.04 & 58 & 30.1 & 65.9 & 2.2 \\
\hline Rockway & $40^{\circ} 30.0^{\prime}$ & $73^{\circ} 58.6^{\prime}$ & 1 & 0.07 & - & 1.1 & 1.7 & 1.5 \\
\hline Shooters & $40^{\circ} 38.7^{\prime}$ & $74^{\circ} 10.3^{\prime}$ & 87 & 4.1 & 210 & 19.7 & 42.3 & 2.1 \\
\hline Union City & $40^{\circ} 47.0^{\prime}$ & $73^{\circ} 59.5^{\prime}$ & 49 & 3.2 & - & 6.2 & 18.1 & 2.9 \\
\hline Ward Point & $40^{\circ} 30.5^{\prime}$ & $74^{\circ} 15.4^{\prime}$ & 20 & 1.46 & 14 & 5.4 & - & - \\
\hline West Beach & $48^{\circ} 23.5^{\prime}$ & $122^{\circ} 40.0^{\prime}$ & 2 & 0.08 & - & 1.5 & 3.7 & 2.5 \\
\hline Ambient SW & & & & & 2.3 & & & \\
\hline
\end{tabular}

nation constants in Landrum (1988). Only biphenyl was used from Landrum (1988) because the elimination constants given for other PAHs exhibited coefficients of variation greater than $40 \%$.

\section{RESULTS}

The site locations and selected sediment properties are listed in Table 1. The sediment samples contained a range of PAHs commonly found in contaminated urban waterways. These sediments contained alkylsubstituted PAHs, indicating input from petroleum products, and relatively large amounts of high molecular weight non-substituted PAHs, indicating input from combustion products or creosote (Fig. 1). All figures with PAHs on the abscissa were plotted in terms of increasing chemical hydrophobicity as determined by $K_{\text {ow }}$ (Meador et al. 1995). All of the PAHs in sediment were highly correlated because all pair combinations

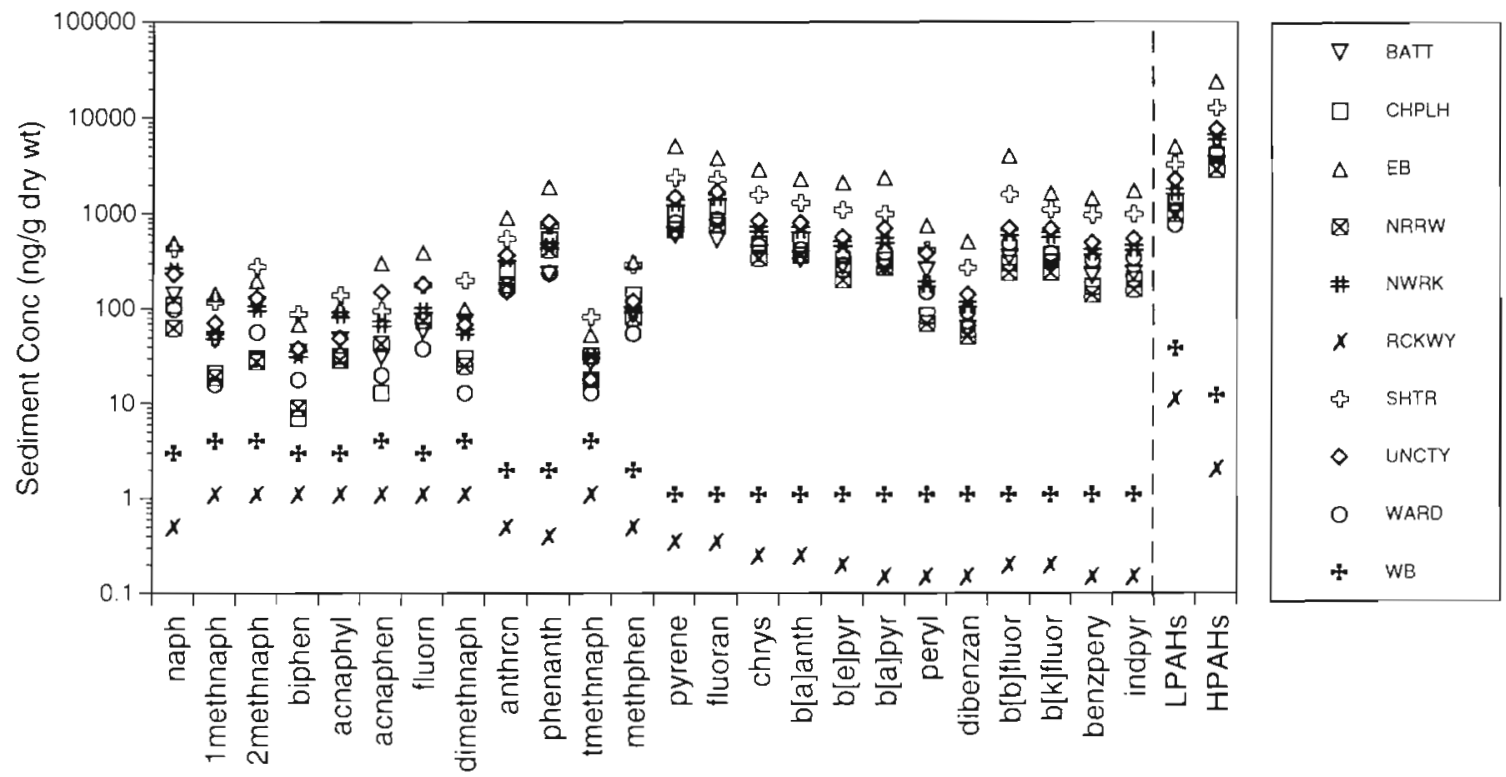

Fig. 1. Polycyclic aromatic hydrocarbons (PAH) in sediment. Plotted by increasing hydrophobicity as determined by the octanolwater partition coefficient $\left(K_{0 w}\right)$. Sites: The Battery (BATT), Chapel Hill (CHPL). Elliott Bay (EB), The Narrows (NRRW), Newark Bay (NWRK), Rockaway (RCKWY), Shooters Island (SHTR), Union City (UNCTY), Ward Point (WARD), and West Beach (WB). All from Hudson-Raritan estuary (New York, USA) except Elliott Bay and West Beach (Washington, USA). Low molecular weight PAHs (LPAHs) from naphthalene through 1-methylphenanthrene and high molecular weight PAHs (HPAHs) from pyrene through indeno[1,2,3-cd]-pyrene. LPA.Hs and HPAHs are sums. PAH abbreviations given in Table 2 
Fig. 2. Sum of low molecular weight polycyclic aromatic hydrocarbons (LPAH) in sediment plotted against percentage total organic carbon (TOC). Sites as in Fig. 1. The sites NWRK, CHPL, and NRRW constitute a group of low TOC sites whose PAHs correlated to sediment TOC differently than the remaining sites

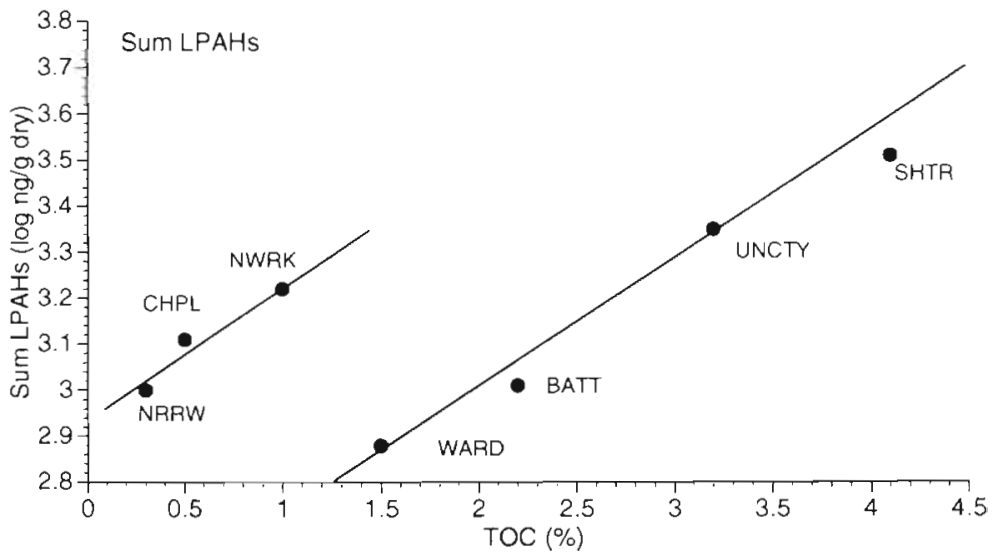

of the 12 LPAHs over sites (e.g. fluorene vs anthracene, over all 10 sites) exhibited correlation coefficients ( $\mathrm{r}$ ) greater than $0.95(n=66)$ and correlations for all pair combinations of the $12 \mathrm{HPAHs}$ were greater than 0.99 $(\mathrm{n}=66)$.

Due to the proximity of sites, a linear correlation between sediment TOC and PAH concentration was expected due to either: (1) an association of waterborne PAHs with the organic carbon of sediment; or (2) an accumulation of fine particles laden with PAHs. Instead we observed 2 distinct groups for the sum of LPAHs (Fig. 2) and HPAHs versus TOC (HPAHs not shown, but similar). Because the low TOC sites displayed possible different accumulation patterns for PAHs in sediment, we suspected that they may produce PAH partitioning behavior different from the other sites. Conversely, local variability in sources of PAHs may contribute to such a pattern; however, these sites were interspersed with the high TOC sites in this study. Other studies, such as Stainken et al. (1983), have found a high correlation between grain size and extractable hydrocarbons which is probably due to an association with increasing TOC. Grain size and TOC in our study were highly correlated ( $\mathrm{r}=0.93)$; hence, either factor can be used for correlational analysis.

Tissue burdens of LPAHs were similar for both species, but for HPAHs they were much higher in Armandia brevis (Table 2). A paired t-test for each chemical determined that many of the HPAHs were significantly higher in the polychaete when compared to the amphipod. The sum of all PAHs expressed as nmol $\mathrm{g}^{-1}$ is shown for both species in Table 1 . When the mean $\mathrm{BAF}_{\text {loc }}$ was examined (Fig 3), the difference between species appeared to be slight for the LPAHs, but was dramatic for the HPAHs. Within the HPAHs series, the amphipod $\mathrm{BAF}_{\text {loc }}$ declined precipitously with increasing chemical hydrophobicity; however, the polychaete maintained essentially equal partitioning over all HPAHs, but displayed a declining trend for the most hydrophobic HPAHs. The ratios of mean $\mathrm{BAF}_{10 \mathrm{C}}$ (poly-
Fig. 3. Armandia brevis and Rhepoxynius abronius. Bioaccumulation factor. Mean and SEM of Day 10 $\mathrm{BAF}_{\text {loc }}$ (lipid normalized tissue concentration of PAH divided by organic carbon normalized sediment concentration of PAH). Low TOC sites not corrected. Order of chemicals as in Fig. 1 LPAHs and HPAHs are sums

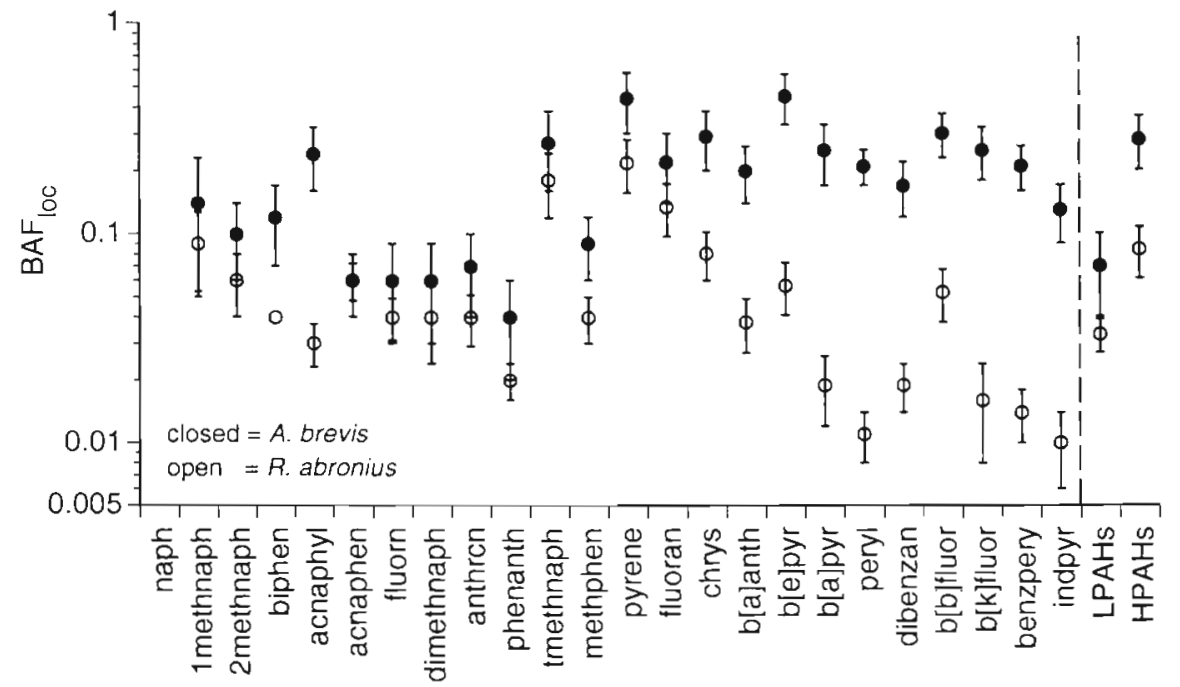


Table 2. Polycyclic aromatic hydrocarbons (PAH). Log $K_{0 w}: \log _{10}$ octanol-water partition coefficient; values from Meador et al. (1995). Log $K_{\text {oc.total }} \log _{10}$ organic carbon normalized partition coefficient using total PAH in interstitial water (IW) ( $\mathrm{n}=7$ ). Amphipod and polychaete tissue concentrations for all matching treatment sites $(n=6)$. Bold polychaete tissue concentrations are significantly $(\alpha=0.002)$ greater than those for amphipod tissue based on paired $t$-test between species and corrected for the number of comparisons. \% IW free: $I W_{\text {free }} / I W_{\text {tor }} \times 100(n=7)$. In this table, $I W_{\text {tree }}$ from Eq. (6) with standard DOC-IW partition coefficient $\left(K_{d x c}\right)$. -: insufficient data. See 'Results' for details

\begin{tabular}{|c|c|c|c|c|c|c|c|c|c|c|}
\hline \multirow[t]{3}{*}{ Chemical } & \multirow[t]{3}{*}{ Abbrev } & \multirow[t]{3}{*}{$\log K_{\text {ow }}$} & \multicolumn{2}{|c|}{ Log $K_{\text {oc,total }}$} & \multicolumn{4}{|c|}{ Tissue $\left(\mathrm{ng} \mathrm{g}^{-1} \mathrm{dry} w \mathrm{t}\right)$} & \multicolumn{2}{|c|}{$\%$ IW free } \\
\hline & & & \multirow[t]{2}{*}{ Mean } & \multirow[t]{2}{*}{$\mathrm{SD}$} & \multirow{2}{*}{\multicolumn{2}{|c|}{$\begin{array}{l}\text { Amphipod } \\
\text { Mean SEM }\end{array}$}} & \multirow{2}{*}{\multicolumn{2}{|c|}{$\begin{array}{l}\text { Polychaete } \\
\text { Mean SEM }\end{array}$}} & \multirow[t]{2}{*}{ Mean } & \multirow[t]{2}{*}{$\mathrm{SD}$} \\
\hline & & & & & & & & & & \\
\hline \multicolumn{11}{|l|}{ LPAHs } \\
\hline Naphthalene & naph & 3.34 & 5.56 & 0.28 & - & - & - & - & 97.6 & 2.4 \\
\hline 1-Methylnaphthalene & 1 methnaph & 3.88 & 5.59 & 0.29 & 15 & 12 & 17 & 9 & 92.6 & 7.2 \\
\hline 2-Methylnaphthalene & 2methnaph & 3.91 & 5.78 & 0.24 & 20 & 15 & 28 & 10 & 92.1 & 7.6 \\
\hline Biphenyl & biphen & 3.98 & 6.00 & 0.22 & 7 & 4 & 13 & - & 91.0 & 8.7 \\
\hline Acenaphthylene & acnaphyl & 4.08 & 5.78 & 0.30 & 8 & 7 & 46 & 14 & 89.0 & 10.5 \\
\hline Acenaphthene & acnaphen & 4.08 & 6.06 & 0.32 & 14 & 10 & 12 & 3 & 89.0 & 10.5 \\
\hline Fluorene & fluorn & 4.22 & 6.06 & 0.18 & 14 & 8 & 17 & 4 & 86.0 & 13.1 \\
\hline 2,6-Dimethylnaphthalene & dmethnaph & 4.42 & 5.92 & 0.32 & 6 & 3 & 14 & 4 & 80.5 & 17.7 \\
\hline Anthracene & anthren & 4.53 & 6.46 & 0.27 & 33 & 24 & 63 & 21 & 77.2 & 20.2 \\
\hline Phenanthrene & phenanth & 4.53 & 6.55 & 0.33 & 37 & 13 & 48 & 9 & 77.1 & 20.3 \\
\hline 2,3,5-Trimethylnaphthalene & tmethnaph & 4.83 & 5.22 & 0.29 & 23 & 12 & 21 & 4 & 66.5 & 26.9 \\
\hline 1-Methylphenanthrene & methphen & 5.15 & 6.19 & 0.11 & 18 & 9 & 28 & 6 & 54.4 & 31.1 \\
\hline \multicolumn{11}{|l|}{ HPAHs } \\
\hline Pyrene & pyrene & 5.07 & 6.42 & 0.44 & 944 & 925 & 1.622 & 568 & 57.4 & 30.4 \\
\hline Fluoranthene & fluoran & 5.24 & 6.47 & 0.15 & 676 & 715 & 797 & 289 & 50.9 & 31.5 \\
\hline Chrysene & chrys & 5.77 & 6.96 & 0.41 & 224 & 202 & 635 & 191 & 31.3 & 26.9 \\
\hline Benz[a]anthracene & $\mathrm{b}[\mathrm{a}]$ anth & 5.90 & 7.05 & 0.55 & 96 & 102 & 389 & 114 & 27.0 & 24.4 \\
\hline Benzo[e]pyrene & b[e]pyr & 6.10 & 6.88 & 0.51 & 103 & 92 & 701 & 196 & 20.5 & 19.9 \\
\hline Benzo[a]pyrene & $\mathrm{b}[\mathrm{a}]$ pyr & 6.23 & 6.92 & 0.56 & 32 & 36 & 408 & 130 & 16.8 & 17.0 \\
\hline Perylene & peryl & 6.39 & 7.02 & 0.58 & 9 & 4 & 150 & 18 & 13.0 & 13.6 \\
\hline Dibenz $[\mathrm{a}, \mathrm{h}]$ anthracene & dibenzan & 6.47 & 6.97 & 0.46 & 7 & 5 & 64 & 20 & 11.3 & 12.0 \\
\hline Benzo[b]fluoranthene & $\mathrm{b}$ [b]fluor & 6.52 & 7.08 & 0.54 & 115 & 105 & 593 & 154 & 10.2 & 11.0 \\
\hline Benzo[k]fluoranthene & $b[k]$ fluor & 6.73 & 6.80 & 0.51 & 22 & 21 & 437 & 122 & 6.9 & 7.6 \\
\hline Benzo[ghi]perylene & benzpery & 7.03 & 6.85 & 0.56 & 21 & 13 & 260 & 72 & 3.7 & 4.2 \\
\hline Indeno[ $1,2,3$-cd]pyrene & indpyr & 7.43 & 6.98 & 0.57 & 13 & 10 & 167 & 45 & 1.6 & 1.8 \\
\hline Sum LPAHs & & - & 5.96 & 0.27 & 177 & 67 & 262 & 56 & - & - \\
\hline Sum HPAHs & & - & 6.57 & 0.31 & 2261 & 2213 & 6222 & 1887 & - & - \\
\hline
\end{tabular}

chaete/amphipod) in Table 3 show that the amphipod and polychaete were relatively close for the LPAHs but that the polychaete $\mathrm{BAF}_{\mathrm{loc}}$ values for the HPAHs were considerably higher. The ratio between species for the summed HPAH BAF loc values was only 3.3 (Table 3 ) because of pyrene and fluoranthene, which accounted for a large portion of the summed HPAHs in tissue. Because the amphipod probably received most of its tissue PAHs from ventilated IW and the polychaete received its body burden through IW and sediment ingestion, a ratio of the concentrations of PAHs in amphipod:polychaete may indicate the proportion of tissue burden in the polychaete due to uptake through IW (Table 2).

For both species, the 3 sites with low TOC (Fig. 2) produced reduced $\mathrm{BAF}_{\text {loc }}$ values compared to the other 4 sites. If these anomalous $\mathrm{BAF}_{\text {loc }}$ values were recalculated (data not shown) by dividing Sed ${ }_{o c}$ by a factor of
5, the values for these sites would have increased to follow the pattern set by the high TOC sites. By using this correction, the overall $\mathrm{BAF}_{\text {loc }}$ mean for each site would have increased slightly and a much lower variation about the mean would occur (SD reduced $>40 \%$ for most PAHs). Because this correction is somewhat ad hoc, we present all $\mathrm{BAF}_{\mathrm{loc}}$ values as uncorrected in order to show the strength of the overall pattern.

Interstitial water concentrations of PAHs were generally low and relatively uniform for most sites (Fig 4). Even though the HPAHs were more abundant in sediment than the LPAHs, they were expected to partition to a lesser degree than the LPAHs which led to similar IW concentrations over the entire range of PAHs for some of the sites. In general the sediments with high concentrations of PAHs (e.g. Elliott Bay and Shooters Island) produced the highest IW concentrations. Two of the HPAH compounds (pyrene and fluoranthene) were high in sed- 
iment and IW for all sites and 2 others (dibenz[a,h]anthracene and perylene) were generally very low.

When the organic carbon normalized partition coefficients $\left(K_{o c, \text { total }}\right)$ were calculated, an interesting pattern emerged (Fig. 5a, Table 2). Based on the octanol-water partition coefficient $\left(K_{o w}\right)$ as a predictor of $K_{o c}$ (Di Toro et al. 1991) our LPAH $K_{\text {oc,total }}$ values were approximately 2 orders of magnitude higher than expected, which was caused by lower than expected IW concentrations. When calculated in terms of the free compound in IW (using Eq. 6 with $K_{\text {doc }}=0.1 K_{\text {ow }}$ ), the $K_{\text {oc, iree }}$ displayed consistently higher values over the entire range of HPAHs and the variability between sites for a given PAH was reduced over all PAHs (Fig. 5b). From this data we calculated the percentage of the total compound that would be freely dissolved in IW (Table 2).

The $\mathrm{BCF}_{\text {total }}$ was plotted for each species and a strong pattern emerged (Fig. 6a). (One notable exception was benzo[b]fluoranthene which behaved like a PAH with less hydrophobicity.) It appears that there was little difference between the 2 species in the LPAH series, but when HPAHs were considered, the amphipod showed a sharp decline with increasing chemical hydrophobicity. Because we assumed that the amphipod received most of its body burden from IW and that some of the PAH would be sorbed to DOC in the IW and not available to the amphipods, we calculated the

Table 3. Rhepoxynius abronius and Armandia brevis. Polycyclic aromatic hydrocarbons (PAH). Correlation is product-moment correlation coefficient ( $\mathrm{r}$ ) for amphipod and polychaete tissue concentrations to interstitial water (IW) and sediment concentrations $\left(n=5\right.$ to 10 ). For all correlations, IW total is total and I $_{\text {free }}$ is free concentration in IW [using 2 DOC-IW partition coefficients $\left(K_{\text {doc }}\right): 0.1 \times$ the octanol-water partition coefficient $\left(K_{o w}\right)$ for most sites and $1.0 K_{\text {ow }}$ for low DOC sites in Table 1 ]. First 4 chemicals had low sample size ( $\mathrm{n}=2$ to 4 ) for most measurements. P-A: correlation between polychaete and amphipod tissue concentrations for all matched sites $(n=6)$. Sed-IW free: correlation between sediment and free IW concentrations $(n=8)$. All correlations based on $\log _{10}$ treatment concentrations. $B A F_{l s c}$ : lipid and sediment organic carbon normalized bioaccumulation factor; P/A: ratio of the polychaete and amphipod $B A F_{10 c}$ values. $\mathrm{BCF}_{\text {free }}$ : mean $\log _{10}$ bioconcentration factor (dry wt) on Day 10 based on IW free (using only the standard $\left.K_{d o c}=0.1 K_{\text {ow }}\right)$ for treatment sites $(n=8)$. SD: standard deviation; SEM: standard error of the mean. -: insufficient data. See text for details and equations

\begin{tabular}{|c|c|c|c|c|c|c|c|c|c|c|c|c|c|}
\hline \multirow[t]{3}{*}{ Chemical } & \multicolumn{9}{|c|}{ Correlations $(\mathrm{r})$} & \multirow{3}{*}{$\begin{array}{c}\mathrm{BAF}_{\text {loc }} \\
\mathrm{P} / \mathrm{A}\end{array}$} & \multirow{2}{*}{\multicolumn{3}{|c|}{$\begin{array}{c}\text { BCF } F_{\text {tree }} \\
\text { amphipod }\end{array}$}} \\
\hline & \multicolumn{3}{|c|}{ Amphipod tissue } & \multicolumn{4}{|c|}{ Polychaete tissue } & \multirow{2}{*}{\multicolumn{2}{|c|}{ P-A Sed-IW }} & & & & \\
\hline & IW & $I_{\text {free }}$ & Sed & IW total & $\mathrm{IW}_{\mathrm{fret}}$ & Sed & $\operatorname{Sed}_{\mathrm{oc}}$ & & & & Mean & $\mathrm{SD}$ & SEM \\
\hline \multicolumn{14}{|l|}{ LPAHs } \\
\hline Naphthalene & - & - & - & - & - & - & - & - & 0.02 & - & - & - & - \\
\hline 1-Methylnaphthalene & -0.62 & -0.70 & -0.22 & - & - & - & - & - & 0.79 & 1.7 & 3.36 & 0.35 & 0.14 \\
\hline 2-Methylnaphthalene & -0.76 & -0.80 & -0.31 & - & - & -0.39 & -0.28 & - & 0.15 & 1.8 & 3.43 & 0.51 & 0.21 \\
\hline Biphenyl & -0.40 & -0.42 & 0.17 & - & - & -0.61 & -0.25 & - & 0.61 & 3.1 & 3.69 & 0.39 & 0.20 \\
\hline Acenaphthylene & 0.44 & 0.49 & 0.71 & 0.28 & 0.35 & 0.72 & 0.01 & 0.61 & 0.66 & 7.0 & 3.36 & 0.27 & 0.11 \\
\hline Acenaphthene & 0.76 & 0.80 & 0.64 & 0.62 & 0.70 & 0.54 & -0.11 & 0.83 & 0.75 & 1.1 & 3.97 & 0.26 & 0.11 \\
\hline Fluorene & 0.59 & 0.62 & 0.24 & -0.59 & -0.52 & -0.13 & -0.13 & 0.38 & 0.92 & 1.7 & 3.64 & 0.28 & 0.10 \\
\hline 2,6-Dimethylnaphthalene & 0.64 & 0.45 & 0.06 & -0.14 & -0.20 & -0.43 & -0.29 & 0.87 & 0.71 & 1.7 & 3.47 & 0.18 & 0.07 \\
\hline Anthracene & 0.96 & 0.94 & 0.81 & 0.86 & 0.86 & 0.68 & -0.36 & 0.98 & 0.97 & 2.0 & 4.10 & 0.21 & 0.08 \\
\hline Phenanthrene & 0.70 & 0.77 & 0.76 & 0.38 & 0.46 & 0.05 & -0.82 & 0.22 & 0.87 & 2.2 & 3.96 & 0.17 & 0.07 \\
\hline 2,3,5-Trimethylnaphthalene & 0.24 & -0.04 & 0.66 & 0.46 & 0.21 & 0.62 & -0.59 & 0.88 & 0.22 & 1.5 & 3.63 & 0.47 & 0.18 \\
\hline 1-Methylphenanthrene & 0.64 & 0.22 & 0.67 & 0.22 & -0.08 & 0.43 & -0.89 & 0.94 & 0.45 & 2.3 & 4.17 & 0.49 & 0.18 \\
\hline \multicolumn{14}{|l|}{ HPAHs } \\
\hline Pyrene & 0.94 & 0.90 & 0.89 & 0.89 & 0.74 & 0.73 & -0.27 & 0.99 & 0.95 & 2.0 & 5.05 & 0.32 & 0.12 \\
\hline Fluoranthene & 0.90 & 0.84 & 0.79 & 0.96 & 0.86 & 0.62 & -0.32 & 0.99 & 0.85 & 1.6 & 5.09 & 0.46 & 0.17 \\
\hline Chrysene & 0.93 & 0.94 & 0.90 & 0.84 & 0.95 & 0.82 & -0.15 & 0.99 & 0.93 & 3.6 & 5.64 & 0.37 & 0.14 \\
\hline Benz|a]anthracene & 0.88 & 0.92 & 0.27 & 0.67 & 0.81 & 0.62 & -0.26 & 0.98 & 0.91 & 5.3 & 5.51 & 0.47 & 0.18 \\
\hline Benzo[e]pyrene & 0.87 & 0.90 & 0.93 & 0.57 & 0.79 & 0.80 & 0.14 & 0.96 & 0.92 & 7.8 & 5.69 & 0.48 & 0.18 \\
\hline Benzola]pyrene & 0.89 & 0.94 & 0.89 & 0.56 & 0.80 & 0.70 & -0.01 & 0.98 & 0.89 & 12.9 & 5.39 & 0.61 & 0.23 \\
\hline Perylene & 0.61 & 0.76 & 0.71 & -0.01 & 0.04 & 0.41 & -0.33 & 0.62 & 0.84 & 18.6 & 5.44 & 0.48 & 0.18 \\
\hline Dibenz $[\mathrm{a}, \mathrm{h}]$ anthracene & 0.84 & 0.91 & 0.94 & 0.45 & 0.64 & 0.74 & 0.02 & 0.86 & 0.89 & 9.3 & 5.65 & 0.56 & 0.21 \\
\hline Benzo|b]fluoranthene & 0.84 & 0.86 & 0.93 & 0.46 & 0.85 & 0.78 & 0.18 & 0.97 & 0.84 & 5.6 & 6.24 & 0.67 & 0.25 \\
\hline Benzolk]fluoranthene & 0.90 & 0.95 & 0.93 & 0.63 & 0.83 & 0.69 & 0.05 & 0.89 & 0.95 & 15.6 & 5.60 & 0.58 & 0.22 \\
\hline Benzo|ghi]perylene & 0.75 & 0.90 & 0.82 & 0.21 & 0.50 & 0.75 & 0.14 & 0.93 & 0.86 & 14.5 & 6.00 & 0.55 & 0.21 \\
\hline Indeno $1,2,3$-cd]pyrene & 0.84 & 0.95 & 0.90 & 0.24 & 0.46 & 0.68 & 0.01 & 0.74 & 0.86 & 12.5 & 6.32 & 0.61 & 0.23 \\
\hline Sum LPAHs & 0.65 & 0.67 & 0.75 & 0.16 & 0.19 & 0.47 & -0.67 & 0.11 & 0.76 & 2.2 & 3.40 & 0.24 & 0.09 \\
\hline Sum HPAHs & 0.96 & 0.92 & 0.47 & 0.87 & 0.84 & 0.77 & -0.15 & 0.99 & 0.96 & 3.3 & 5.13 & 0.36 & 0.14 \\
\hline
\end{tabular}




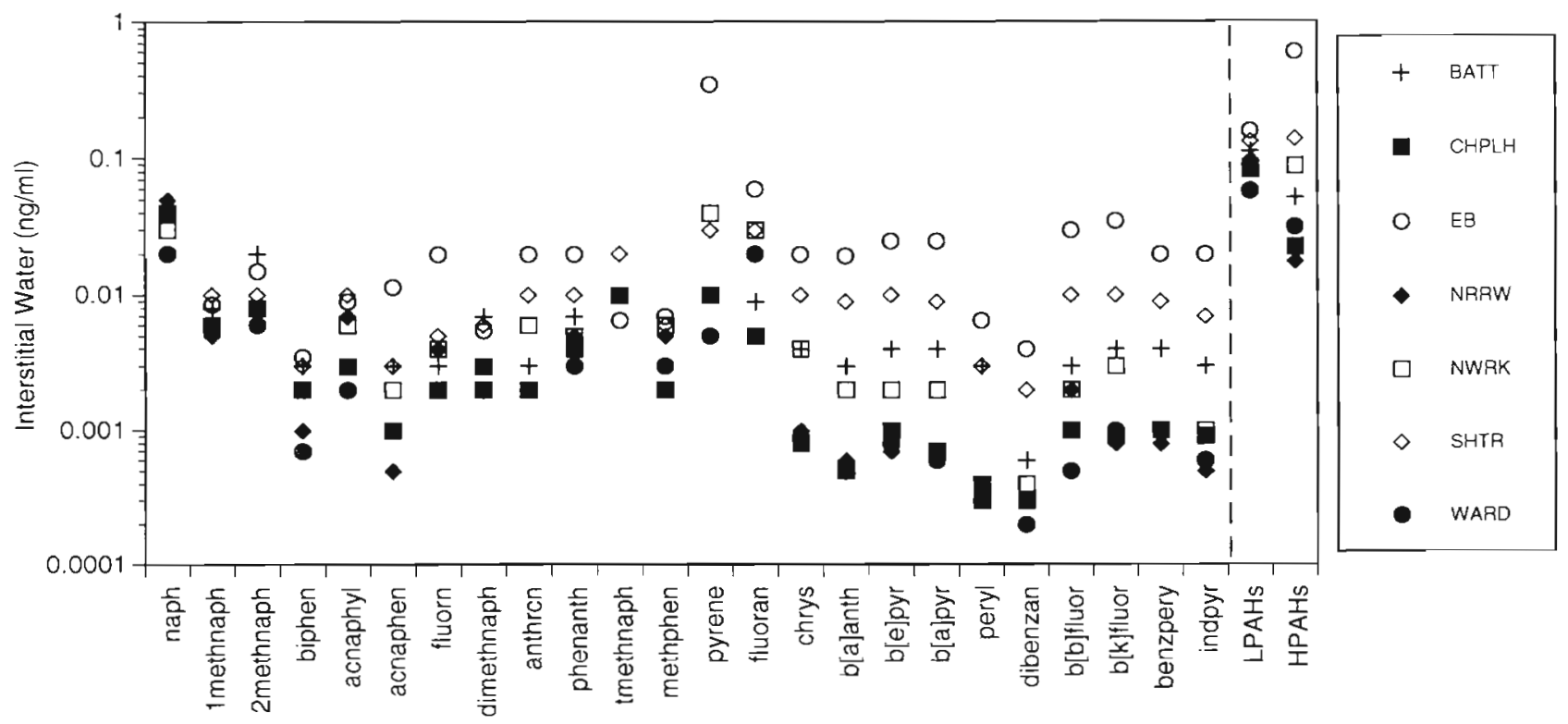

Fig. 4. PAHs in interstitial water. Sites and order of chemicals as in Fig. 1. Solid symbols: low dissolved organic carbon (DOC) sites. LPAHs and HPAHs are sums

a
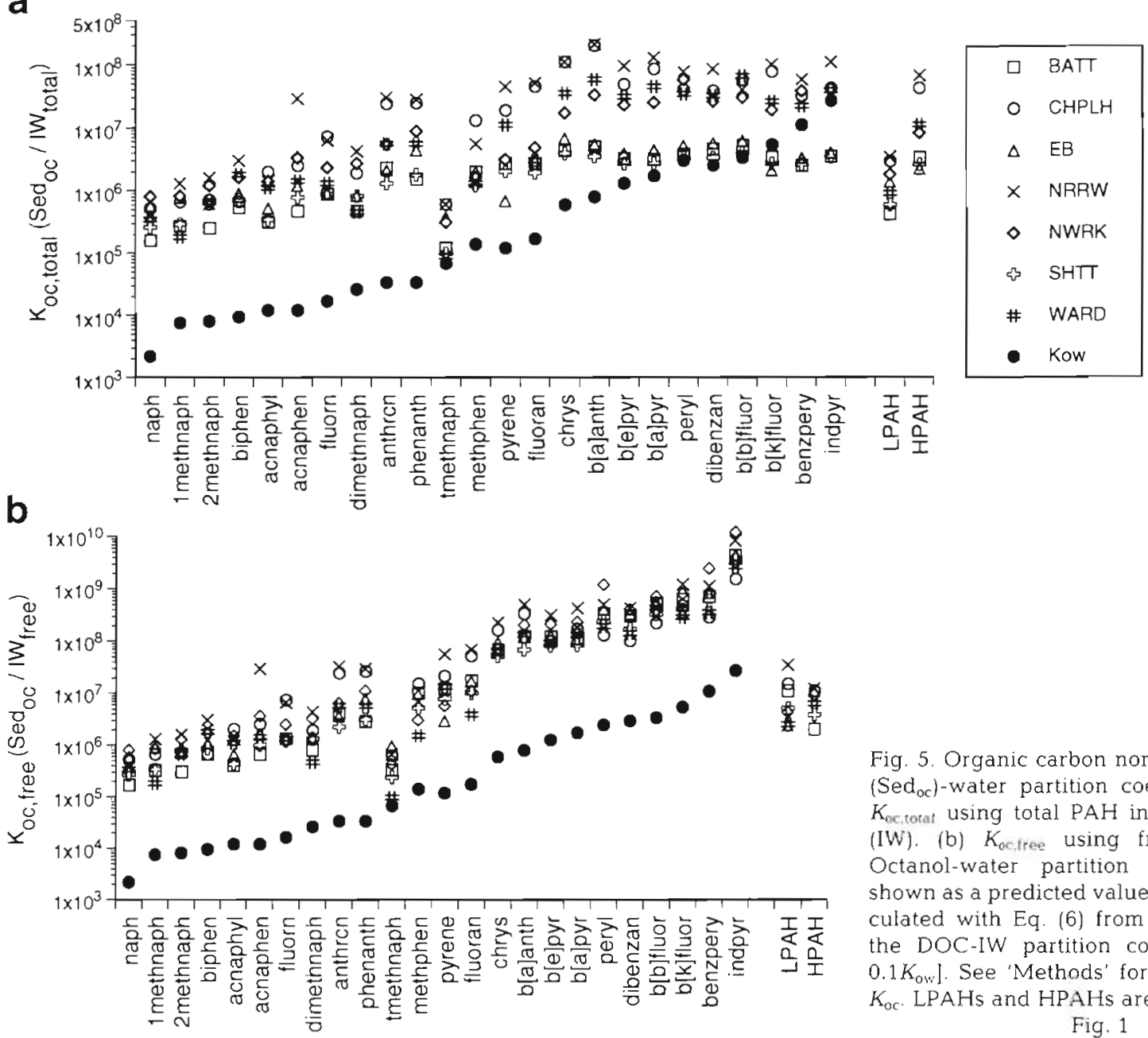

Fig. 5. Organic carbon normalized sediment (Sed $\mathrm{Soc}_{\mathrm{oc}}$-water partition coefficient $\left(K_{\mathrm{oc}}\right)$. (a) $K_{\text {octotal }}$ using total PAH in interstitial water (IW). (b) $K_{\text {octree }}$ using free PAH in IW. Octanol-water partition coefficient $\left(K_{o w}\right)$ shown as a predicted value for $K_{\mathrm{oc}}$. IW ftee calculated with Eq. (6) from 'Methods' [using the DOC-IW partition coefficient $\left(K_{\text {doc }}\right)=$ $0.1 K_{\text {ow }}$. See 'Methods' for determination of $K_{\text {oc }}$. LPAHs and HPAHs are sums. Sites as in Fig. 1 
Fig. 6. Rhepoxynius abronius and Armandia brevis. Bioconcentration factor $(B C F)$. Mean and SEM of Day 10 BCFs (dry weight tissue concentration divided by IW concentration). (a) $B C F_{\text {total }}$ for amphipod and polychaete. (b) $B C F_{\text {total }}$ and $\mathrm{BCF}_{\text {Iree }}$ for $R$. abronius. ( ) $B C F$ calculated with total PAH in IW: (O) BCF calculated with free PAH in IW (using Eq. 6 and the standard $K_{\text {doc }}$ for all sites). ( $\boldsymbol{*}$ ) Predicted BCF (see 'Methods' for details). Order of chemicals as in Fig. 1 a

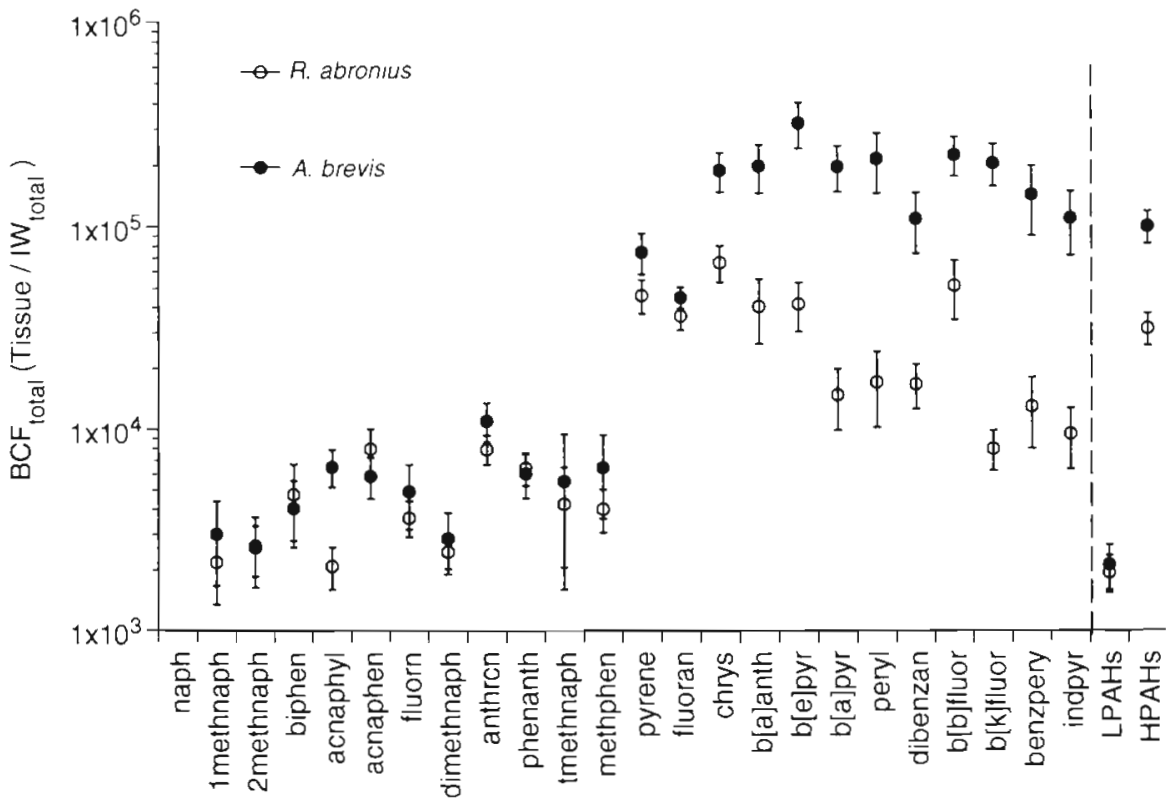

b

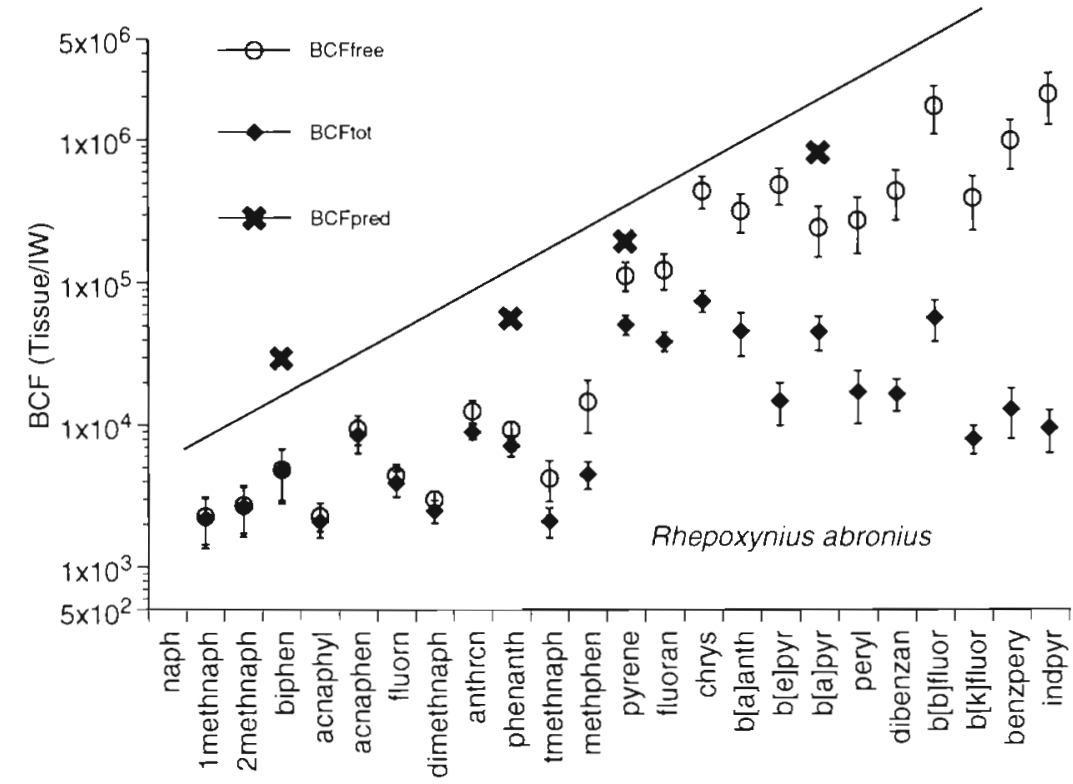

concentration of free PAH in the IW (using our standard $K_{\mathrm{doc}}=0.1 K_{\mathrm{ow}}$ ) (see 'Methods'). Although still variable, the values and trend for the observed $\mathrm{BCF}_{\text {free }}$ for amphipods are in much better agreement with the values and trend for the predicted BCF than that determined for the observed $\mathrm{BCF}_{\text {total }}$ (Fig. 6b). When $\mathrm{BCF}_{\text {free }}$ was plotted with the standard $K_{\text {doc }}$ value of $0.1 K_{\text {ow }}$ the 3 sites considered to have 'low' DOC (Table 1) produced anomalously low $B C F_{\text {tree }}$ values over the HPAHs. If a stronger $K_{\text {doc }}\left(=1.0 K_{o w}\right)$ was used to calculate $\mathrm{BCF}_{\text {free }}$ for only these 3 sites, the BCFs for these sites would improve considerably and follow the pattern set by the majority of the sites; hence, reducing variability about the mean (data not shown). Although not exhaustive, values greater or less than 1.0 for this second $K_{\text {doc }}$ produced poorer fits to the predicted BCF.

Because our determinations for the $K_{\mathrm{oc}}$ and BCF values greatly improved by using free PAH concentrations in IW, we plotted amphipod tissue burdens against free PAHs in IW to see if the high correlations held. An example is plotted in Fig. 7, and all correlations are listed in Table 3 . Even with the DOC correction to compute free PAH, the high correlations were maintained, but only by using the $2 K_{\text {doc }}$ values described above. Although the 4 sites (Battery, Newark, Shooters, and Elliott Bay) with higher DOC 


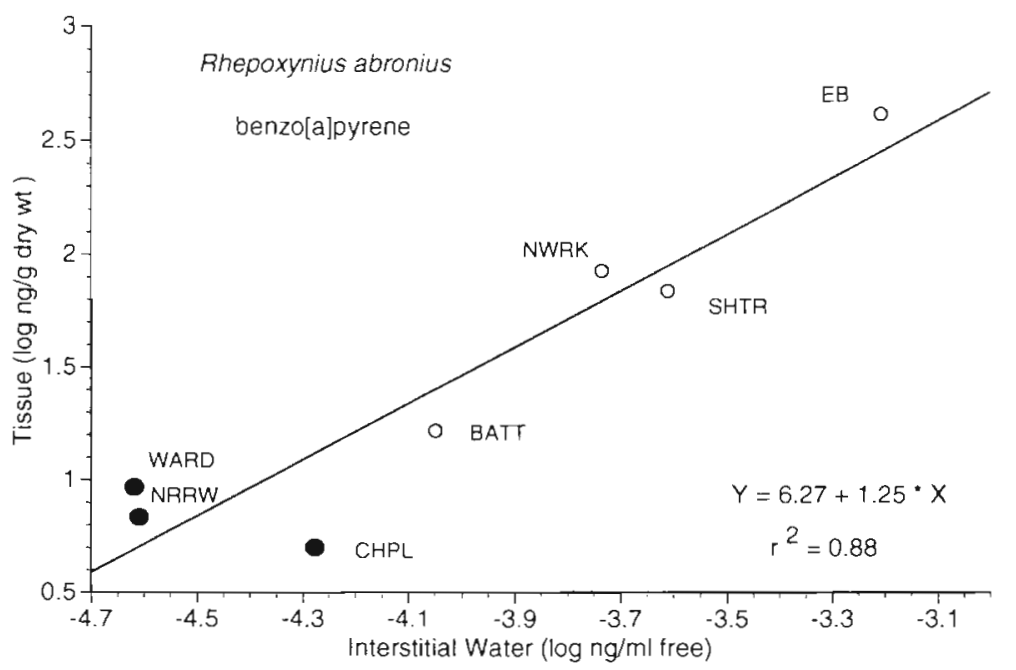

Fig. 7. Rhepoxynius abronius. Concentration of benzo[a]pyrene in tissue versus free compound in IW. IW tree calculated with Eq. (6). (O) $K_{\text {doc }}=$ $0.1 K_{\text {ow }}$ (high DOC sites); $\left(K_{\text {doc }}=1.0 K_{\text {ow }}\right.$ (low DOC sites). Sites as in Fig 1

values were calculated with our standard $K_{\text {doc }}$ which gave a good fit, if the IW concentrations for the low DOC sites (Ward Pt, The Narrows, and Chapel Hill) in Table 1 were calculated with a stronger $K_{\text {doc }}\left(=1.0 K_{\text {ow }}\right.$ ) the correlation improved greatly. The correlations for amphipod and IW $W_{\text {free }}$ using only the standard $K_{\text {doc }}$ produced similar correlations over the LPAHs, but much lower correlation coefficients $(0.2$ to 0.6$)$ for most HPAHs, hence the best correlations were with IW total or IW $W_{\text {tree }}$ using the $2 K_{\text {doc }}$ values (Table 3 ).

We examined correlations between tissue PAH concentrations and those concentrations in bulk sediment, organic carbon normalized sediment, total IW, and free IW for both species to find the highest values which may indicate the probable route of exposure (Table 3 ) We also show the correlations between tissue concentrations of each species and the correlations between sediment and IW free $_{\text {froncentrations (using both } K_{\text {doc }}}$ values) to highlight how similarly the species responded to the sites and the similarity in concentrations between compartments (Table 3). The correlations for LPAHs were generally not as strong as those seen for the HPAHs, which may be due in part to the LPAHs having variable concentrations close to the limit of detection. Other correlations were weak, probably due to the narrow range in concentration for sediment, tissue, and IW over sites (e.g trimethylnaphthalene). As expected, the strongest correlation for the amphipod was between. IW free and tissue concentrations. For the polychaete the pattern was less clear with sediment and IW trading off in importance. Even though there was a high correlation between amphipod and polychaete tissue concentrations, especially within the HPAHs series, the polychaete body burden was generally much higher than that in the amphipod. One example, which is characteristic of all HPAHs, is

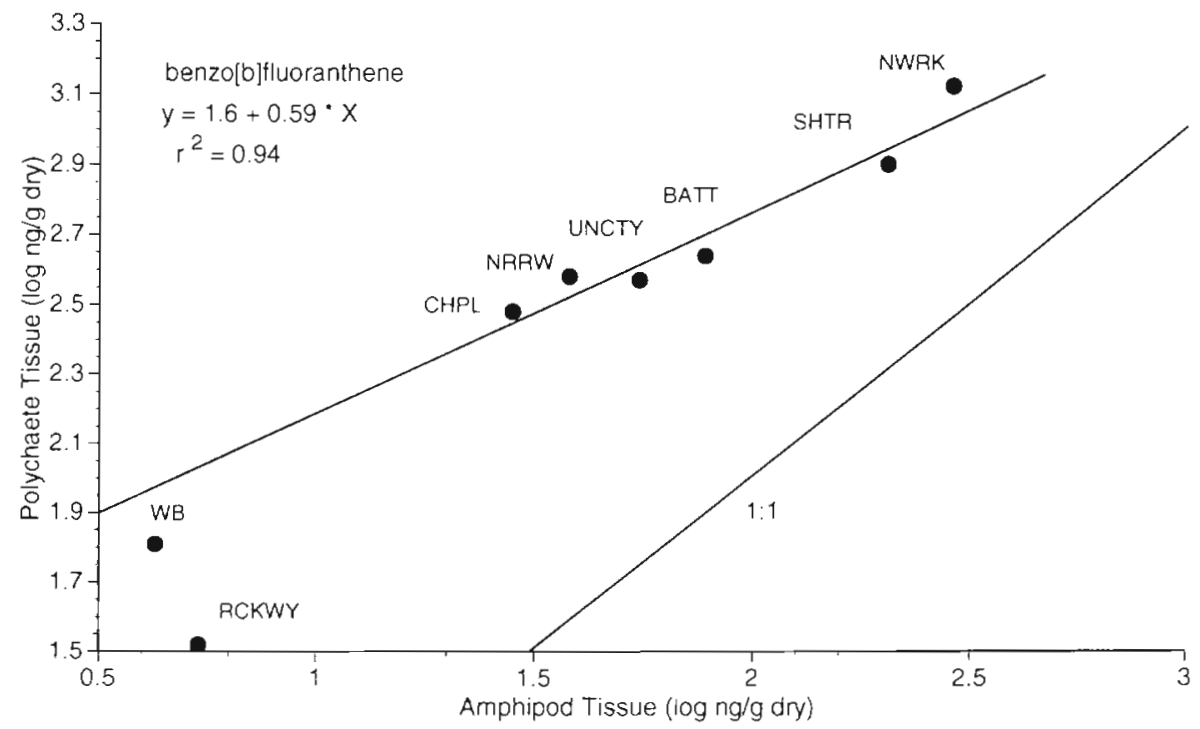

Fig. 8. Armandia brevis and Rhepoxynius abronius. Tissue burden in polychaete and amphipod. Plot showing relationship of benzo[b]fluoranthene in tissues of $A$, brevis to $R$ abronius. $1: 1$ is the line of equal concentration. Sites as in Fig. 1. WB and RCKWY included to show background tissue burdens but not used to calculate correlation coefficient 
plotted in Fig. 8. The 1:1 ratio was also plotted showing how much higher the polychaete body burden was relative to the amphipod body burden.

\section{DISCUSSION}

In this comparative study, we found similar concentrations of LPAHs and very different concentrations of HPAHs in the tissues of 2 infaunal invertebrates with different modes of feeding. The BCFs for both species over the LPAHs were very similar probably because both acquired the majority of their PAH burdens from interstitial water. Even though sediment-water partitioning was approximately 2 orders of magnitude less than expected, the BCFs for the amphipod were much closer to expectation (after correcting for metabolism and pre-steady-state conditions), but only when free PAH was considered. Because it is possible to find sediments dominated by PAHs from several sources, it may be necessary to measure IW directly to predict sediment toxicity and determine bioaccumulation for sediment-dwelling invertebrates. In order to assess the utility of EPT, many additional studies with field collected sediments are needed.

\section{Sediment-water partitioning}

The low IW concentrations for these PAHs and the lack of predictable $K_{\text {or }}$ values is very important. Because equilibrium partitioning theory depends on predicting IW concentrations for sediment quality criteria, reliable and predictable $K_{o c}$ values are essential In our study, $K_{\text {oc, iree }}$ values for PAHs were elevated by about a factor of 100 because of lower than expected IW concentrations, whereas in another study of these same sediments, the $K_{\mathrm{oc} \text { f }}$ values for PCBs (tri-, tetra-, penta-, and hexachlorobiphenyls) were close to expectation (Meador unpubl.). Other authors have also found higher than expected $K_{o c}$ values for PAHs or partitioning behavior other than expected and alluded to the possibility that combustion PAHs may behave differently than other organic contaminants in their predicted desorption to water (Farrington et al. 1983, Prahl \& Carpenter 1983, Varanasi et al. 1985, Pruell et al. 1986, Readman et al. 1987, Socha \& Carpenter 1987 McGroddy \& Farrington 1995). Although the origin of PAHs in our samples could not be unequivocally established, the predominance of HPAHs suggests the sources are combustion products (vis-à-vis petroleum sources). These observations on PAH partitioning behavior are important because many studies (LaFlamme \& Hites 1978, Hites et al. 1980, Bieri et al 1986, Readman et al. 1987) have found that combus- tion PAHs often predominate in sediments from around the world. Many studies of PAH partitioning report IW concentrations as expected; however, most of these lab studies were performed by spiking the sediment with individual chemicals and then allowing the sediment and interstitial water PAHs to approach equilibrium. Laboratory experiments indicate that a large percentage of the partitioning of hydrophobic organic contaminants between sediment and IW occurs within $1 \mathrm{wk}$, with a longer time required for complete equilibrium (Karickhoff 1980, Karickhoff \& Morris 1985, Connaughton et al. 1993). Because our sediments displayed partitioning that was much less than predicted, equilibrium between sediment and IW, as predicted by EPT, may not occur or may take several times longer than expected.

Due to strong sorption with DOC, the concentration of HPAHs in IW will be higher than predicted in water without DOC. It has been shown previously that DOC in IW can enhance dissolved concentrations of hydrophobic compounds (Brownawell \& Farrington 1986, Socha \& Carpenter 1987, Di Toro et al. 1991) which may explain the disparity in observed and predicted $K_{\text {oc total }}$ values for LPAHs and HPAHs in Fig. 5 a. In our study, when we determined the amount of free PAH in IW and calculated the $K_{0 \text { cfree }}$ the values became uniformly elevated above the predicted values and the variability among sites for each compound was greatly reduced (Fig. 5b). These results indicate that IW DOC has a strong influence on PAH concentrations in IW and also shows more clearly the expected partitioning behavior between sediment and IW PAHs. Our data for the percentage of freely dissolved benzo[a]pyrene in IW agrees with that reported by Landrum et al. (1989).

\section{Tissue burdens}

Tissue PAH concentrations for the amphipod and polychaete were very similar over the LPAH series but markedly divergent over the HPAHs which we believe was due to different feeding modes. Interestingly, the correlation between PAH concentrations in polychaete and amphipod tissue was extremely high for the HPAHs (Fig. 8, Table 3), indicating that both species were responding similarly to the sediments, but because the route of exposure was different, vastly different tissue concentrations were attained. The high tissue-to-tissue correlations may be explained by the high correlations between concentrations of PAHs in sediment and IW. The strongest correlations between tissue and environmental exposure for the amphipod occurred with the free PAH concentrations in IW (Table 3), which is consistent with the assumed major 
route of uptake. In most cases, however, the correlations for IW and sediment to tissue were similar. Correlations for Armandia brevis were strong for all exposures except sediment concentration normalized to organic carbon. The correlations for each matrix (IW and sediment) to tissue were not greatly different primarily due to the finding that sediment and IW concentrations were highly correlated with each other, which caused relatively high correlations of tissue to each of these matrices. Because of the closeness in correlations for different exposure routes, we feel that correlations are not a useful indication of the route of exposure, especially when there is high co-correlation between compartments.

Because of the modes of feeding and the assumption that the amphipod was receiving the majority of its PAH tissue burden via ventilated IW, we can infer that the 2 species acquired nearly identical body burdens of LPAHs through IW uptake, and that any contribution of LPAH tissue burden by sediment ingestion to the polychaete was insignificant. Because there was such a strong differential in body burden for the HPAHs, it seems clear that for these very hydrophobic compounds, sediment ingestion is the dominant route of exposure in Armandia brevis. This is in contrast to other studies which concluded that IW is the dominant route of exposure for infaunal invertebrates (Adams 1987, Oliver 1987, Knezovich \& Harrison 1988) but in agreement with those concluding that ingestion can be a major contributor to body burden of hydrophobic compounds (Lynch \& Johnson 1982, McLeese \& Burridge 1987, Boese et al. 1990, Weston 1990). It appears that both deposit and non-deposit feeding infaunal invertebrates will acquire most of their body burden of LPAHs through IW , however, sediment ingestion may be the dominant route of uptake for deposit feeders when hydrophobic compounds exceed a $\log K_{\text {ow }}$ of ca 5.5. Because this was a short-term test and because we are unsure if the amphipod was feeding (Meador 1993), the dietary route of exposure for this species under field conditions may or may not be significant in the determination of tissue burdens. Less than optimal feeding is an artifact of laboratory holding which must be considered in these types of bioassays.

At this time we cannot rule out the possible contribution of PAH uptake due to contact with the sediment; however, the large difference between tissue burdens for the HPAHs indicates that this type of contribution to tissue burden is probably small. If sediment contact were important, it is unlikely that a mechanism would exist that would allow similar LPAH uptake by sediment contact in both species and little uptake of HPAHs in amphipods.

Although these experiments were conducted for only $10 \mathrm{~d}$, we expected the LPAHs in tissue to be close to steady-state conditions and the HPAHs to be within a factor of 2 or 3 of steady state (Lee et al. 1993, Landrum et a]. 1994, Meador et al. 1995). Even though sediment-water equilibrium partitioning was much lower than expected, partitioning between tissue and water was expected to behave according to prevailing theory. Other studies have demonstrated rapid uptake and close to steady-state conditions within $10 \mathrm{~d}$ for deposit feeding polychaetes exposed to PAHs (Lake et al. 1985. Weston 1990). Considering the overall patterns observed in our data, a reduction from steady state by a factor of 2 to 3 would not change our overall conclusions.

Even though there were very large differences in body burdens for most HPAHs, when expressed in terms of summed PAHs, the tissue concentrations between species were relatively close. The mean (SD) ratio between species of summed PAH over sites was only $2.6(0.7)$ (Table 1$)$. Because the HPAHs pyrene and fluoranthene behaved more like LPAHs, in that their main route of uptake was probably through IW and their concentrations were relatively high in IW, both species accumulated similar high tissue concentrations (Table 2). The lethal body burden for narcotic chemicals such as parent PAHs is believed to be in the range of 5 to $30 \mu \mathrm{mol} \mathrm{g}^{-1}$ dry weight (McCarty 1991). In our study, summed PAHs in tissue were more than 125 times lower than this critical body burden. Because sediment PAH profiles can vary, one with abundant HPAHs will probably produce a different toxicity response in these 2 species compared to a sediment with a PAH profile skewed towards the LPAHs.

An important point when attempting to assess bioaccumulation is the relative ability of a species to metabolize the compound of interest. A related study with these 2 species found that metabolites accounted for $65 \%$ of the total. body burden for the polychaete Armandia brevis and $85 \%$ for the amphipod Rhepoxynius abronius after $10 \mathrm{~d}$ of continuous exposure to benzola]pyrene in sediment (E. Casilias, J. P. Meador, P. D. Plesha \& C. A. Rice unpubl.). Supporting evidence comes from Reichert et al. (1985), who found similar biotransformation results for $R$. abronius exposed to benzo[a]pyrene in spiked sediment. Increasing the amphipod body burden for similar parent HPAHs by a factor of $2.3(35 \% / 15 \%$; total compound as parent compound in polychaete/amphipod) would make the comparison between species more equitable. We feel that this 2.3-fold difference in metabolic capacity between species for benzo[a]pyrene will be similar for other PAHs. A review of the literature on marine invertebrate species that metabolize PAHs found only minor differences in elimination rates (expressed as half-lives) within species over a range of HPAHs (Meador et al. 1995). Using this correction for 
all PAHs, the ratio of polychaete to amphipod tissue concentrations would be close to unity for the LPAHs and 5- to 9-fold higher for the HPAHs.

We believe that the observed differences in PAH accumulation between the amphipod and polychaete were not due to possible toxicokinetic differences but are consistent with mode of feeding and chemical bioavailability. Because of the similar LPAH BCFs observed for these 2 species we can conclude that the ratio between the uptake $\left(k_{1}\right)$ and elimination $\left(k_{2}\right)$ rates (which can define $\mathrm{BCF} ;=k_{1} / k_{2}$ ) for these PAHs is similar. In light of the review by Meador et al. (1995) that indicates small within species differences in elimination rates for different HPAHs and a study showing that within species uptake rates may increase by a factor of 2 or 3 with increasing hydrophobicity (Landrum 1988), major differences between the amphipod and polychaete in uptake and elimination rates leading to large differences in HPAH tissue burdens were not expected. When amphipod tissue burdens are corrected for metabolism and less than steady-state conditions (increase by a factor of 6.6 for metabolism and 2 to 3 for steady state), many BCFs are very close to the predicted BCFs calculated with data for an amphipod species with weak metabolic capacity for PAHs, indicating that IW is the probable route of exposure. We would like to emphasize that the observed results for tissue burdens are consistent with our assumptions about bioavailability and toxicokinetic processes and that future work on the rates of uptake and elimination of these hydrophobic contaminants in infaunal invertebrates will greatly improve our understanding of bioaccumulation.

\section{Accumulation factors}

The $\mathrm{BAF}_{\mathrm{loc}}$ values reported here for polychaetes are similar to those reported by others for infaunal invertebrates from field collected samples (Foster \& Wright 1988, Bierman 1990, Ferraro et al. 1990). Some of the variability in $\mathrm{BAF}_{\text {loc }}$ for a given $\mathrm{PAH}$ over sites may be due to different ingestion rates of sediment, which has been demonstrated for an infaunal polychaete (Weston 1990). However, in our study there was no uniform pattern over PAHs. One consistent source of variability in $\mathrm{BAF}_{\text {loc }} \mathrm{s}$ came from the low TOC sites (The Narrows, Chapel Hill, and Newark) (Fig. 2). Our low TOC sites (0.3 to $0.5 \%$ TOC) produced low BAF loc values (about 5 times below the mean for sites with TOC > $0.5 \%$ ), which is contrary to other studies that found high $\mathrm{BAF}_{\text {loc }}$ (or AF) for low TOC sites (Foster \& Wright 1988 , Weston 1990). In our case, these low TOC sites produced tissue burdens that were lower than they should have been for a given $\mathrm{Sed}_{\mathrm{oc}}$. This is contrary to Weston (1990), who found higher tissue burdens for a given
Sedoc when TOC was low, presumably due to increased feeding in low TOC sediment. In our study, the lower than expected body burdens may be due to the lack of an enhanced feeding rate by the non-selective deposit feeder and possible stronger sorption of $\mathrm{PAH}$ on sediment organic carbon. We conclude that PAHs in the low TOC sites may have been more tightly sorbed and less available to the organisms than PAHs at the high TOC sites. Further evidence of strong sorption by organic carbon at the low TOC sites can be seen by comparing IW concentrations for Newark (low TOC group) and The Battery (high TOC group) (Fig. 2) Even though sediment PAH concentrations were higher for Newark (Fig. 1), The Battery produced generally higher IW concentrations for all PAHs (Fig. 4) including free HPAHs (with the notable exception of pyrene and fluoranthene).

If tissue concentrations in Armandia brevis were corrected for metabolism (increase tissue concentration by 2.9), the median $\mathrm{BAF}_{\text {loc }}$ values would be within $20 \%$ (LPAHs) to $50 \%$ (HPAHs) of the theoretical maximum of 1.7 (Bierman 1990, Lee 1992, Lee et al. 1993). Our LPAH values were low possibly due to higher elimination than assumed or rapid depuration during the $6 \mathrm{~h}$ gut purge. These data indicate that even though partitioning of sediment PAHs to IW was 1 to 2 orders of magnitude less than expected, partitioning into a deposit feeding organism was in much better agreement with the expected model (see Lee 1992). Hence, even though hydrophobic PAHs may be more tightly bound to the sediment particles in an aqueous environment, when these same particles are in a polychaete gut, the bound PAHs appear to be more labile to the organism.

As hydrophobicity increased, the apparent BCF $\left(\mathrm{BCF}_{\text {tolal }}\right.$ based on total PAH in IW) for Rhepoxynius abronius decreased, which was probably due to the increased fraction of PAHs in the IW that was not available for uptake due to sorption on DOC. It is well known that PAHs associated with DOC will decrease the amount of the total PAH that is available to organisms (Landrum et al. 1985, 1987, McCarthy 1989) and is probably important only for very hydrophobic compounds at natural DOC levels. By correcting for DOC partitioning, the BCFs for the amphipod became more predictable, although still variable (Fig. 6b). It is interesting to note that even though sediment concentrations for these HPAHs were high (ppm range), the amphipod was responding to IW concentrations in the range of 0.1 to 1.0 part per trillion.

The use of $2 K_{\text {doc }}$ values vastly improved the variability around the mean BCF (data not shown) and the tissuematrix correlations were greatly improved. We conclude that there may have been some qualitative difference in DOC between sites (such as variable humic acid content) 
or that HPAHs exhibit stronger affinity to DOC when concentrations were low. Several studies have shown that $K_{\mathrm{doc}}$ values vary substantially, which could be related to DOC composition (Landrum et al. 1984, Gauthier et al. 1986, 1987, Caron \& Suffet 1989, McCarthy et al. 1989, Kukkonen et al. 1991). Another possible cause of variable $K_{\text {doc }}$ is redox state. Hunchak-Kariouk (1992) found $K_{\mathrm{doc}}$ values for tetrachlorobiphenyl about an order of magnitude higher in oxic porewater compared to those observed in anoxic porewater. In our study, porewater producing higher $K_{\mathrm{doc}}$ values were from sites with coarser sediment, which would tend to have porewater that is more oxic than sediments with a higher percentage of finer particles.

In conclusion, the higher the percentage of fine particles in a sediment the more organic carbon it will contain, and, when exposed to urban sources, these sediments will have higher contaminant loads because of their complexing and sorption capacity (Marcus et al. 1988, Olsen et al. 1993). Because of the strong differential of body burdens of HPAHs, we feel that the finegrain muds with high TOC and high IW DOC that often contain high contaminant loads may be somewhat protective to infauna that are not sediment ingesters (e.g. suspension-feeding clams), while at the same time posing the greatest hazard to those that do ingest sediment. Consequently, an accurate determination of a sediment's bioaccumulation and toxicity potential in an artificial, non steady-state laboratory exercise or in a highly dynamic urban estuary, is completely dependent on choosing the most appropriate organism for the hypothesis to be tested.

Acknowledgements. We thank Donald Brown, Nicolaus Adams, Thomas Merculief, Susan Pierce and Wayne Dyer (NMFS) for their expert contributions. TOC in sediment and DOC in interstitial water was analyzed by Kathy Krogslund of the Dept. of Oceanography at the University of Washington. We thank Casimir Rice, Robert Snider, and Paul Plesha (NMFS) for help in performing the assays and Drs. John Stein and Cheryl Krone for thorough review of the manuscript. Mention of any trade names does not constitute endorsement by the Department of Commerce.

\section{LITERATURE CITED}

A.PHA (1985) Standard methods for the examination of water and wastewater, 16th edn. APHA, AWWA and WPCF. Am Public Health Assoc, Washington, DC

ASTM (1990) Standard guide for conducting 10 day static sediment toxicity tests with marine and estuarine amphipods. Annual Book of ASTM Standards, Standard E 1367-90. American Society for Testing and Materials, Philadelphia

Adams WJ (1987) Bioavallability of neutral lipophilic organic chemicals contained on sediments: a review. In: Dickson KL, Maki AW. Brungs WA (eds) Fate and effects of sed.ment-bound chemicals in aquatic systems. Pergamon Press, New York, p 219-244
Bieri RH, Hein C, Huggett RJ, Shou P, Slone II, Smith C, Su CW (1986) Polycyclic aromatic hydrocarbons in surface sediments from the Elizabeth River subestuary. Int $J$ environ analyt Chem 26:97-113

Bierman VJ (1990) Equilibrium partitioning and biomagnification of organic chemicals in benthic animals. Environ Sci Technol 23:1407-1412

Boese BL, Lee H II, Specht DT, Randall RC, Winsor MH (1990) Comparison of aqueous and solid-phase uptake for hexachlorobenzene in the tellinid clam Macoma nasuta (Conrad): a mass balance approach. Environ Toxicol Chem 9: $221-231$

Brownawell BJ, Farrington JW (1986) Biogeochemistry of PCBs in interstitial water of a coastal marine sediment. Geochim Cosmochim Acta 50:157-169

Buchanan JB, Kain JM (1971) Measurement of the physical and chemical environment. Sediments. In: Holme NA MacIntyre AD (eds) Methods for studying the marine benthos. IBP handbook number 16. Blackwell Scientific Publs, Oxford, p 30-51

Caron G. Suffet IH (1989) Binding of nonpolar pollutants to dissolved organic carbon. In: Suffet IH, MacCarthy P (eds) Aquatic humic substances: influence on fate and treatment of pollutants. Advances in Chemistry Series 219. American Chemical Society, Washington, DC, p 117-130

Chiou CT, Kile DE, Brinton TI, Malcolm RL, Leenheer JA (1987) A comparison of water solubility enhancements of organic solutes by aquatic humic materials and commerclal humic acids. Environ Sci Technol 21:1231-1234

Connaughton DF, Stedinger JR, Lion LW, Shuler ML (1993) Description of time-varying desorption kinetics: release of naphthalene from contaminated sediments. Environ Sci Technol 27:2397-2403

Di Toro DM, Zarba CS, Hansen D.J, Berry WJ, Swartz RC. Cowan CE, Pavlou SP, Allen HE, Thomas NA, Paquin PR (1991) Technical basis for establishing sediment quality criteria for nonionic organic chemicals using equilibrium partitioning. Environ Toxicol Chem 10:1541-1583

Farrington JW, Goldberg ED, Risebrough RW, Martin JH, Bowen VT (1983) U.S. 'Mussel Watch' 1976-1978: an overview of the trace-metal, DDE, PCB, hydrocarbon, and artificial radionuclide data. Environ Scj Technol 17:490-496

Fauchald K, Jumars PA (1979) The diet of worms: a study of polychaete feeding guilds. Oceanogr mar Biol A Rev 17: 193-284

Ferraro SP, Lee H II, Ozretich RJ, Specht DT (1990) Predicting bioaccumulation potential: a test of a fugacity-based model. Archs environ Contam Toxicol 19:386-394

Foster GD. Wright DA (1988) Unsubstituted polynuclear aromatic hydrocarbons in sediments, clams, and clam worms from Chesapeake Bay. Mar Pollut Bull 19:459-465

Gauthier TD, Seitz WR, Grant CL (1987) Effects of structural and compositional variations of dissolved humic materials on pyrene $K_{o c}$ values. Environ Sci Technol 21:243-248

Gauthier TD, Shane EC, Guerin WF, Seitz WR, Grant CL (1986) Fluorescence quenching method for determining equilibrium constants for polycyclic aromatic bydrocarbons binding to dissolved humic materials. Environ Sci Technol 20:1162-1166

Gray JS (1979) Pollution-induced changes in populations. Phil Trans R Soc Lond B 286:545-561

Hedges JI, Stern J (1984) Carbon and nitrogen determination of carbonate containing soluds. Limnol Oceanogr 29 : $657-663$

Herbes SE, Allen CP (1983) Lupid quantification of freshwater invertebrates: method modification for microquantitation. Can J Fish Aquat Scl 40:1315-1317 
Hites RA, Laflamme RE, Windsor JG Jr, Farrington JW, Deuser WG (1980) Polycyclic aromatic hydrocarbons in an anoxic sediment core from the Pettaquamscutt River (Rhode Island, USA). Geochim Cosmochım Acta 44: $873-878$

Hunchak-Kariouk K (1992) Influence of anoxic pore water dissolved organic matter on the fate and transport of hydrophobic organic pollutants. PhD dissertation, Drexel University, Philadelphia

Jeffries HP (1962) Environmental characteristics of Raritan Bay, a polluted estuary. Limnol Oceanogr 7:21-31

Karickhoff SW (1980) Sorption kinetics of hydrophobic pollutants in natural sediments. In: Baker RA (ed) Contaminants and sediments, Vol 2, Analysis, chemistry, and biology. Ann Arbor Science, Ann Arbor, MI, p 193-205

Karickhoff SW, Morris KR (1985) Sorption dynamics of hydrophobic pollutants in sediment suspensions. Environ Toxicol Chem 4:469-479

Knezovich JP, Harrison FL (1988) The bioavailability of sediment-sorbed chlorobenzenes to larvae of the midge, Chironomus decorus. Ecotoxicol environ Safety 15:226-241

Krahn MM, Ylitalo GM, Joss J, Chan SL (1991) Rapid, semiquantitative screening of sediments for aromatic compounds using sonic extraction and HPLC/fluorescence analysis. Mar environ Res 31:175-196

Kukkonen J, McCarthy JF, Oikari A (1991) Binding and bioavailability of organic micropollutants in natural waters: effects of the quality and quantity of dissolved organic material. In: Baker RA (ed) Organic substances and sediment in water, Vol 3. Lewis Publishers, Chelsea, MI, p 111-127

LaFlamme RE, Hites RA (1978) The global distribution of polycyclic aromatic hydrocarbons in recent sediments. Geochim Cosmochim Acta 42: 289-303

Lake J, Hoffman GL, Schimmel SC (1985) Bioaccumulation of contaminants from Black Rock Harbor dredged material by mussels and polychaetes. Tech Rept D-85-2, U.S. Environmental Protection Agency, Narragansett, RI

Landrum PF (1988) Toxicokinetics of organic xenobiotics in the amphipod, Pontoporeia hoyi: role of physiological and environmental variables. Aquat Toxicol 12:245-271

Landrum PF, Dupuis WS. Kukkonen J (1994) Toxicokinetics and toxicity of sediment-associated pyrene and phenanthrene in Diporeia spp.: examination of equilibrium-partitioning theory and residue-based effects for assessing hazard. Environ Toxicol Chem 13:1769-1780

Landrum PF, Faust WR, Eadie BJ (1989) Bioavailability and toxicity of a mixture of sediment-associated chlorinated hydrocarbons to the amphipod Pontoporeia hoyi. In: Cowgill UM, Williams LR (eds) Aquatic toxicology and hazard assessment, Vol 12. ASTM STP 1027. American Society for Testing and Materials, Philadelphia, p 315-329

Landrum PF, Nihart SR, Eadie BJ, Gardner WS (1984) Reverse-phase separation method for determining pollutant binding to Aldrich humic acid and dissolved organic carbon of natural waters. Environ Sci Technol 18:187-192

Landrum PF, Nihart SR, Eadie BJ, Herchel R (1987) Reduction in bioavailability of organic contaminants to the amphipod Pontoporeia hoyi by organic matter of sediment interstitial waters. Environ Toxicol Chem 6:11-20

Landrum PF, Reinhold MD, Nihart SR, Eadie BJ (1985) Predicting the bioavailability of organic xenobiotic to Pontoporeia hoyi in the presence of humic and fulvic materials and natural dissolved organic matter. Environ Toxicol Chem 4:459-467

Lee H II (1992) Models, muddles, and mud: predicting bioaccumulation of sediment-associated pollutants. In: Bur- ton GA Jr (ed) Sediment toxicity assessment. Lewis Publications, Chelsea, MI, p 267-293

Lee H II, Boese BL, Pelletier J, Winsor M, Specht DT, Randal] RC (1993) Guidance manual: bedded sedıment bioaccumulation tests. U.S. EPA. Report No 600/R-93/183, U.S. EPA, ERL-Narragansett, Rhode Island

Lyes MC (1979) Bioavailability of a hydrocarbon from water and sediment to the marine worm Arenicola marina. Mar Biol 55:121-127

Lynch TR, Johnson HE (1982) Avallability of hexachlorobiphenyl isomer to benthic amphipods from experimentally contaminated natural sediments. In: Pearson JG, Foster RB, Bishop WE (eds) Aquatic toxicology and hazard assessment: fifth conference, ASTM STP 766. American Society for Testing and Materials, Philadelphia, p 273-287

Mackay D (1982) Correlation of bioconcentration factors. Environ Sci Technol 16:274-278

Marcus JM, Swearingen GR, Williams AD, Heizer DD (1988) Polynuclear aromatic hydrocarbons and heavy metals concentrations in sediments at coastal South Carolina marinas. Archs environ Contam Toxicol 17:103-113

McCarthy JF (1989) Bioavailability and toxicity of metals and hydrophobic organic contaminants. In: Suffet IH, MacCarthy P (eds) Aquatic humic substances: influence on fate and treatment of pollutants. Advances in Chemistry Series 219. American Chemical Society, Washington, DC, p 263-277

McCarthy JF, Roberson LE, Burrus LW (1989) Association of benzo(a)pyrene with dissolved organic matter: prediction of $K_{\text {dom }}$ from structural and chemical properties of the organic matter. Chemosphere 19:1911-1920

McCarty LS (1991) Toxicant body residues: Implications for aquatic bioassays with some organic chemicals. In: Mayes MA, Barron MG (eds) Aquatic toxicology and risk assessment, Vol 14. ASTM STP 1124. American Society for Testing and Materials, Philadelphia, p 183-192

McElroy AE, Farrington JW, Teal JM (1989) Bioavailability of polycyclic aromatic hydrocarbons in the aquatic environment. In: Varanasi $U$ (ed) Metabolism of polycyclic aromatic hydrocarbons in the aquatic environment. CRC Press, Boca Raton, p 1-39

McGroddy S, Farrington JW (1995) Sediment-porewater partitioning of polycyclic aromatic hydrocarbons (PAHs) in three cores from Boston Harbor, MA. Environ Toxicol (in press)

McLeese DW, Burridge LE (1987) Comparative accumulation of PAHs in four marine invertebrates. In: Capuzzo JM, Kester DR (eds) Oceanic processes in marine pollution, Vol 1, Biological processes and wastes in the ocean. RE Krieger Publishing, Malabar, FL, p 109-117

Meador JP (1993) The effect of laboratory holding on the toxicity response of marine infaunal amphipods to cadmium and tributyltin. J exp mar Biol Ecol 174:227-242

Meador JP, Stein JE, Reichert WL, Varanasi U (1995) A review on the bioaccumulation of polycyclic aromatic hydrocarbons by marine organisms. Rev environ Contam Toxicol (in press)

Meador JP, Varanasi U, Krone CA (1993) Differential sensitivity of marine infaunal amphipods to tributyltin. Mar Biol 116:231-239

Milliken GA, Johnson JRN (1984) Analysis of messy data, Vol 1, Designed experiments. Lifetime Leaming Publications, London

Oakden JM (1984) Feeding and substrate preference in five species of phoxocephalid amphipods from central California. J crust Biol 4:233-247

Oliver BG (1987) Biouptake of chlorinated hydrocarbons from 
laboratory-spked and field sediments by oligochaete worms. Environ Scl Technol 21:785-790

Oliver JS, Oakden JM, Slattery PN (1982) Phoxocephalid amphipod crustaceans as predators on larvae and juveniles in marine soft-bottom communities. Mar Ecol Prog Ser $7: 179-184$

Olsen CR, Larsen IL, Mulholland PJ, von Damm KL, Grebmeier JM, Schaffner LC, Diaz RJ, Nichols MM (1993) The concept of an equilibrium surface applied to particle sources and contaminant distributions in estuarine sediments. Estuaries 16:683-696

Prahl FG, Carpenter R (1983) Polycyclic aromatic hydrocarbons (PAH)-phase associations in Washington coastal sediment. Geochim Cosmochim Acta 47:1013-1023

Pruell RJ, Lake JL, Davis WR, Quinn JG (1986) Uptake and depuration of organic contaminants by blue mussels (Mytilus edulis) exposed to environmentally contaminated sediment. Mar Biol 91:497-507

Readman JW, Mantoura RFC, Rhead MM (1987) A record of polycyclic aromatic hydrocarbon ( $\mathrm{PAH}$ ) pollution obtained from accreting sediments of the Tamar Estuary, U.K.: evidence for non-equilibrium behaviour of PAH. Sci Total Environ 66:73-94

Reichert WL, Eberhart BTL, Varanasi U (1985) Exposure of two species of deposit feeding amphipods to sedimentassociated $[3 \mathrm{H}]$ benzo[a]pyrene: uptake, metabolism, and covalent binding to tissue macromolecules. Aquat Toxicol 6:45-56

Rice CA, Plesha PD, Casillas E, Mistano DA, Meador JP (1995) Growth and survival of three marine invertebrates species in sediments from the Hudson-Raritan estuary, New York. Environ Toxicol Chem (in press)

Schrap SM, Opperhuizen A (1990) Relationship between bioavailability and hydrophobicity: reduction of the uptake of organic chemicals by fish due to the sorption on particles. Environ Toxicol Chem 9:715-724

Sloan CA, Adams NG, Pearce RW, Brown DW, Chan SL

This article was submitted to the editor
(1993) Northwest fisheries science center organic analytical procedures. In: Lauenstein CG, Cantillo AY (eds) Sampling and analytical methods of the national status and trends program - national benthic surveillance and mussel watch projects 1984-1992, Vol IV, Comprehensive descriptions of trace organic analytical methods. NOAA Tech Memo NOS/ORCA.71:53-97

Socha SB, Carpenter R (1987) Factors affecting pore water hydrocarbon concentrations in Puget Sound sediments. Geochim Cosmochim Acta 51:1273-1284

Stainken DM, Multer HG, Mirecki J (1983) Seasonal patterns of sedimentary hydrocarbons in the Raritan Bay lower New York Bay. Environ Toxicol Chem 2:35-42

Swartz RC, Cole FA, Lamberson JO, Ferraro SP, Schults DW, DeBen WA, Lee H II, Ozretich RJ (1994) Sediment toxicity, contamination and amphipod abundance at a DDT- and dieldrin-contaminated site in San Francisco Bay. Environ Toxicol Chem 13:949-962

Swartz RC, Cole FA, Schults DW, DeBen WA (1986) Ecological changes in the southern California bight near a large sewage outfall: benthic conditions in 1980 and 1983. Mar Ecol Prog Ser 31:1-13

Van Der Kooij LA, van de Meent D, van Leeuwen CJ, Bruggeman W A (1991) Deriving quality criteria for water and sediment from the results of aquatic toxicity tests and product standards: application of the equilibrium partitioning method. Water Res 25:697-705

Varanasi U, Reichert WL, Stein JE, Brown DW, Sanborn HR (1985) Bioavailability and biotransformatıon of aromatic hydrocarbons in benthic organisms exposed to sediment from an urban estuary. Environ Scj Technol 19:836-841

Weston DP (1990) Hydrocarbon bioaccumulation from contaminated sediment by the deposit-feeding polychaete Abarencola pacifica. Mar Biol 107:159-169

Widdows J, Moore SL, Clarke KR, Donkin P (1983) Uptake, tissue distribution and elimination of $\left[1-{ }^{14} \mathrm{C}\right]$ naphthalene in the mussel Mytilus edulis. Mar Biol 76:109-114

Manuscript first received: August 5, 1994

Revised version accepted: February 15, 1995 